DOI: $10.34220 /$ issn.2222-7962/2020.4/10

УДК $630 * 22$

ДРЕВЕСНЫЕ НАСАЖДЕНИЯ ООПТ «ДАЧА БАШКИРЦЕВА»: СОСТОЯНИЕ, ЦЕННОСТНАЯ ЗНАЧИМОСТЬ, ВОЗМОЖНОСТИ РЕИНТЕГРАЦИИ В СОВРЕМЕННУЮ КУЛЬТУРНУЮ ЖИЗНЬ

\author{
аспирант В.В. Володин ${ }^{1}$ \\ доктор биологических наук, профессор Н.Н. Харченко ${ }^{1}$ \\ кандидат сельскохозяйственных наук О.В. Трегубов 2 \\ 1 - ФГБОУ ВО «Воронежский государственный лесотехнический университет имени Г.Ф. Морозова», \\ г. Воронеж, Российская Федерация \\ 2 - ФГБУ «ВНИИЛГИСбиотех», г. Воронеж, Российская Федерация
}

В статье анализируется динамика состояния древесных насаждений ООПТ как часть процесса исторического становления объекта. Рассматривается комплекс основных факторов, определяющих эту динамику. На основе данных изучения объекта выделяются наиболее ценные с различных точек зрения структурные элементы исследуемого природного памятника, в том числе уникальные деревья. Рассматривается целесообразность реконструкции объекта и возможные подходы к ней.

Ключевые слова: Помещичья усадьба, Дача Башкирцева, регулярный парк, липовые аллеи, лесозащитная полоса, уникальные деревья, устойчивость насаждений, возрастные ступени

\title{
TREE PLANTS OF SPNA "BASHKIRTSEV'S HOUSE": STATE, VALUABLE IMPORTANCE, POSSIBILITIES OF REINTEGRATION INTO MODERN CULTURAL LIFE
}

\author{
post-graduate student V.V. Volodin ${ }^{1}$ \\ DSc (Biology),Professor N.N. Kharchenko ${ }^{1}$ \\ $\mathrm{PhD}$ (Agriculture) O.V. Tregubov ${ }^{2}$ \\ 1 - FSBEI HE "Voronezh State University of Forestry and Technologies named after G.F. Morozov", \\ Voronezh, Russian Federation \\ 2 - FSBI "All-Russian Research Institute of Forest Genetics, Breeding and Biotechnology", \\ Voronezh, Russian Federation
}

\begin{abstract}
The article analyzes the dynamics of the state of tree plantations in protected areas as a part of the historical formation process of the object. The complex of the main factors determining this dynamics has been considered. Based on the data of the study, the most valuable (from various points of view) structural elements of the investigated natural monument, including unique trees, are identified. The feasibility of the reconstruction of the object and possible approaches to it has been considered.
\end{abstract}

Keywords: manor house, Bashkirtsev's house, linden alleys, forest protection belt, unique trees, plant sustainability, age stages 


\section{Введение}

В данной статье рассматривается известная многим воронежцам ООПТ «Дача Башкирцева», являющаяся и культурно-историческим, и природным памятником Воронежской земли, драматическая судьба которого соединяет несколько исторических эпох. Исторический и культурологический аспект формирования усадебной культуры 18-19 веков на территории нашего края достаточно подробно освещён в [4], [14] и других работах. Краткая дендрологическая характеристика некоторых ООПТ приведена в [5]. Учёные Воронежского университета О. В. Якименко, И. В. Полунина, А. А. Рудницких проводят общий анализ усадебных комплексов Семилукского района в статье [22]. Однако сколько-нибудь подробного дендрологического анализа объекта рассмотрения автору в литературе не встречалось. В [18] фиксируются границы памятника, находящиеся на его территории объекты, но отсутствует описание насаждений. При этом стоит отметить, что помещичьи усадьбы - это ещё и эксперимент по созданию экокластеров с более чем двухсотлетней историей. Вкратце озвучивается эта тема в [2]. Исследование сохранившихся на территории поместий насаждений даёт возможность зафиксировать результаты этого исторического опыта. В частности этот материал представляет практический интерес с точки зрения изучения устойчивости насаждений, интродукции, гармоничного взаимодействия естественного и рукотворного ландшафтов. В представляемом вашему вниманию материале приводятся результаты первого этапа исследования усадебного комплекса, известного как ООПТ «Дача Башкирцева». Ниже, после краткого описания ландшафта усадьбы и её истории, рассматриваются результаты изучения древостоев верхнего регулярного парка и условий произрастания сохранившихся насаждений. На основе этих данных строятся предварительные выводы о рекреационной и исторической ценности объекта и возможности его реконструкции.

\section{Материалы и методы}

Подготовительный этап данного исследования включал в себя:

- предварительный осмотр объекта;
- изучение картографического материала [18], в частности спутниковых снимков;

- сбор информации об истории объекта по литературным источникам, в сети интернет, при личном общении со старожилами [4, 14, 22, 23].

Далее проводились полевые исследования, состоявшие из следующих видов работ:

- ландшафтный анализ территории, выявление её пространственно-планировочной структуры, рекреационного и эстетического потенциала, степени дигрессии в соответствии с общепринятыми методами $[1,3,10,17]$;

- закладка пробных площадей для пересчёта плодовых деревьев внутри боскетов и уточнения картографических данных в соответствии с ОСТ 56-69-83 [11];

- отбор образцов буром Пресслера у наиболее репрезентативных экземпляров для проведения дендрохронологического анализа насаждений по общепринятым методам [7, 9];

- сплошной пересчёт деревьев в сохранившихся аллейных посадках с фиксацией диаметра, высоты, категории состояния, характерных отклонений от нормы согласно утверждённым методикам [11];

- определение положения уникальных старовозрастных деревьев в соответствии с утвержденными рекомендациями $[10,16]$;

- закладка почвенных разрезов в верхней, регулярной и нижней, пейзажной частях усадебного комплекса согласно утверждённым методикам [13].

Завершающим в данной работе стал камеральный этап, в ходе которого была выделена значимая информация из пересчётных ведомостей; проведён анализ почвенных образцов, проведён анализ отобранных кернов с использованием графической программы Corel-Photo-Paint X6. Сопоставление полученной информации с данными первого этапа исследования, а также с усреднёнными табличными данными хода роста соответствующих древесных пород [19] позволили построить картину эволюции объекта и наметить возможные подходы в работе с ним. 


\section{Природопользование}

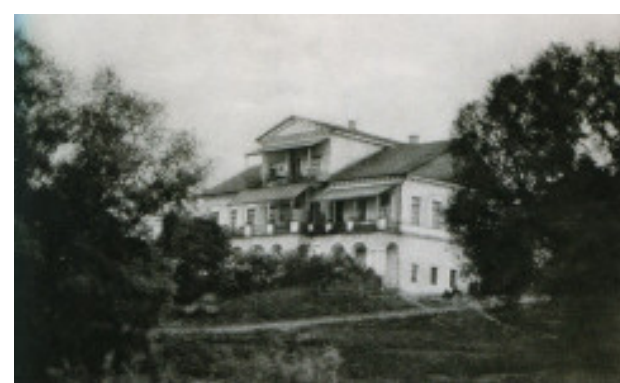

Рис 1. Особняк усадьбы Башкирцева. Предположительно 1880- годы. Источник: интернет [23]

\section{Результаты и обсуждение}

ООПТ «Дача Башкирцева» расположена по адресу г. Семилуки, ул. Дача, 1А буквально в десяти с половиной километрах от здания областного правительства, если мерить по прямой. Площадь усадьбы составляла в пересчёте на современные меры 22 га, в границы ООПТ вошли 19 га (рис. 3). Расположена усадьба на коренном берегу Дона северо-восточной ориентации, ниже впадения в него реки Девица. В высотной структуре комплекса выделяются три уровня: верхний регулярный парк на плодородном плакоре, имеющем небольшой наклон 1,5-2 градуса в сторону русла; средний - сформированная из надпойменной террасы площадка, на которой и построено здание усадьбы, и нижний - верхняя часть пойменной долины с пейзажным парком и прудом. Перепад высот между верхним и нижним парком порядка 10-12 м. И если на (рис. 1) представлен особняк в пору его расцвета, то на рисунке (2) здание усадьбы показано вскоре после освобождения Воронежа от нацистских войск. Среди оголившегося пейзажа хорошо видна средняя насыпная терраса, на которой стоит здание усадьбы. Уровни обозначены стрелками: 1 - верхний парк; 2 - усадьба; 3 - нижний парк.

Структура эта чрезвычайно символична и заслуживает отдельного рассмотрения. Здесь укажем лишь, что она соответствует трёхуровневому представлению о мире в традиционных культурах [30]. Мост через Девицу приводит как раз на средний, объединяющий, уровень, с которого разворачивается вид на особняк.

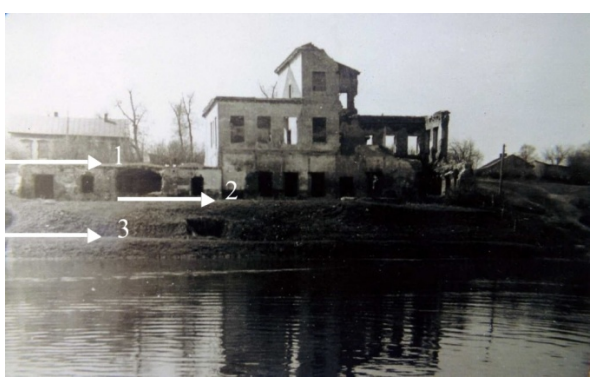

Рис 2. Особняк усадьбы Башкирцева, 1943 г. Источник интернет [23]. Пометки на основе авторских измерений

Второй этаж особняка и смотровая площадка, расположенная правее, находится на уроне верхнего парка. Отсюда открывается перспектива на Донскую долину, частично загораживаемая сейчас разросшимися елями послевоенной посадки. Верхний регулярный парк образован четырьмя боскетами, в которых высажены соответственно четыре плодовых сада (рис. 4, 20). Боскеты разделены аллеями, структуру которых мы рассмотрим ниже.

По периметру четырёхчастная мандала регулярного сада также была окружена аллеями, выполнявшими по совместительству функции ветрозащитных лесополос. К сожалению, сохранились они не везде. Со стороны реки Девица аллея оказалась срезана застройкой. Аллея, разграничивающая верхний парк и надпойменную террасу, спускающуюся в нижний парк, также оказалась во многом утраченной. Площадь верхнего парка составляет порядка 12 гектар.

Сохранившиеся насаждения нижнего парка имеют площадь порядка 5 гектар. На данный момент структура утрачена, и это фактически лесопарковая зона, явно нуждающаяся в санитарной вырубке. Пруд, к которому спускается поперечная аллея верхнего парка, по утверждению старожилов заполнялся водой до 1987-1989 годов. Но изменился гидрологический режим местности, мелеющий Дон фактически не разливается и пруд перестал заполнятся. Хотя на фотографиях 70-х годов прошлого века, выполненных Дмитрием Свириденко [23], в нём ещё купаются дети (рис. 5). Безусловно, нижний парк нуждается в исследовании, однако темой данной статьи является верхний регулярный парк. 


\section{Природользование}

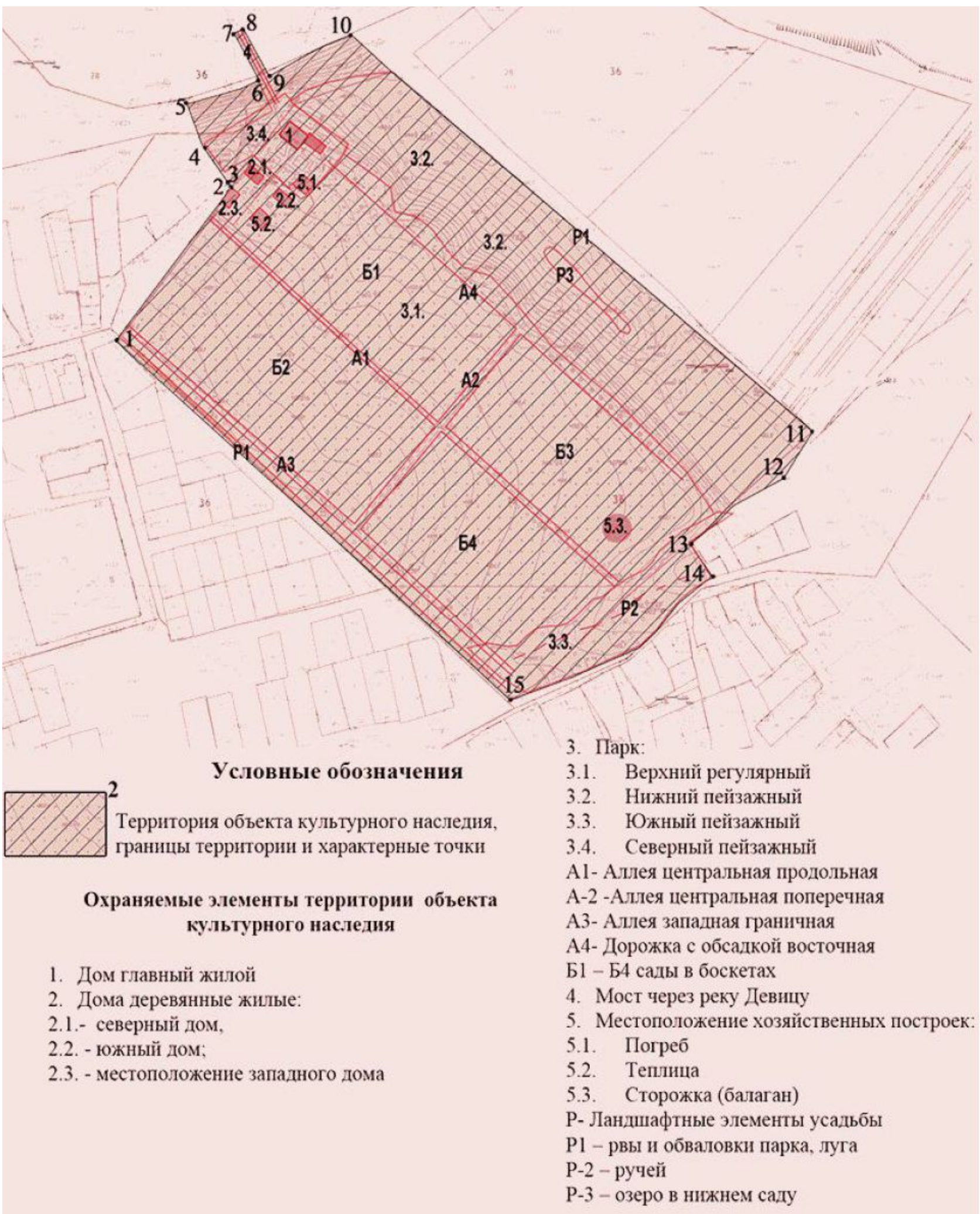

Рис. 3. Современный план ООПТ. Источник: Управление по охране культурного наследия Воронежской области [18]. 


\section{Природопользование}

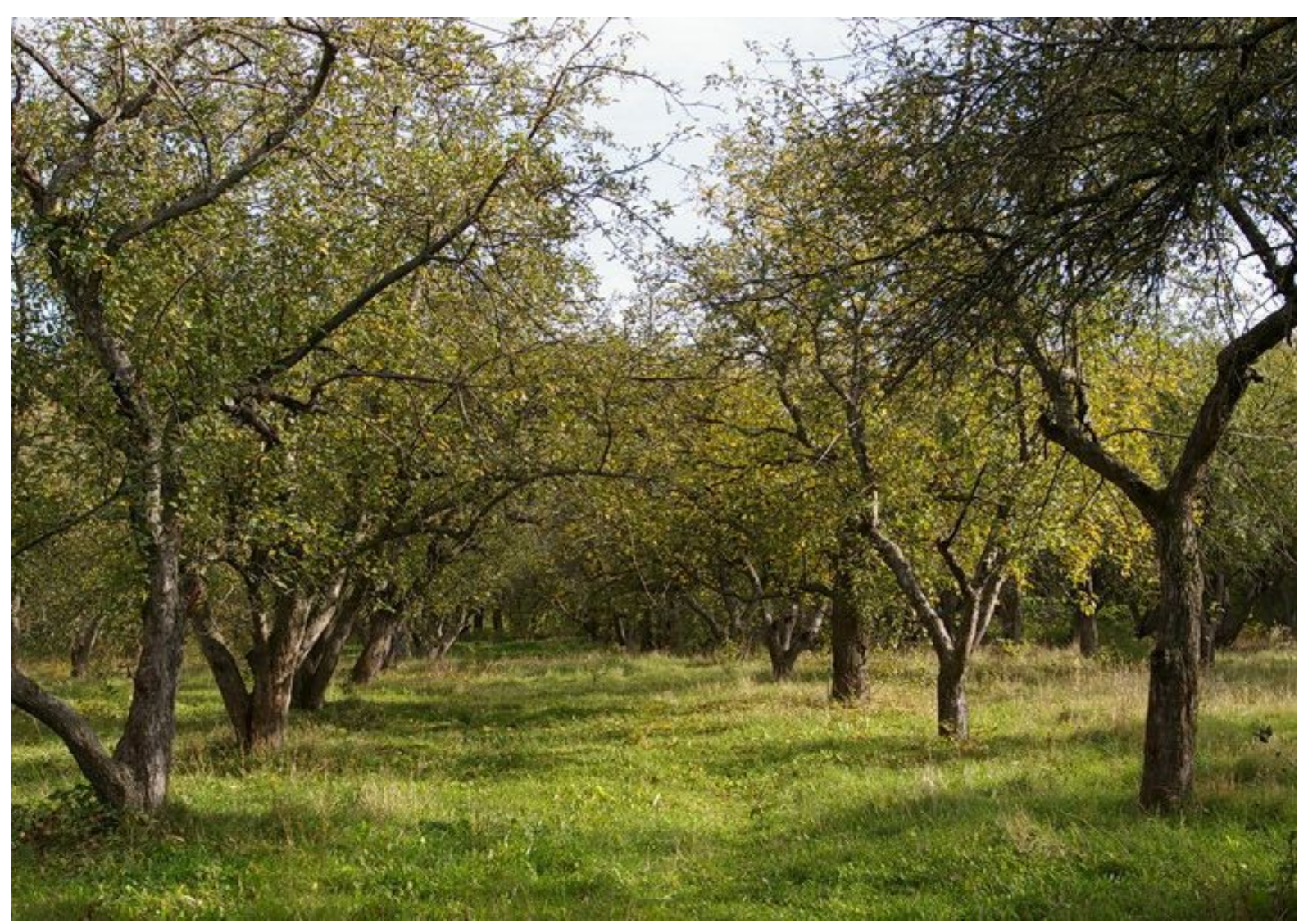

Рис. 4. Яблоневый сад в боскете Б1. Собственное фото авторов.

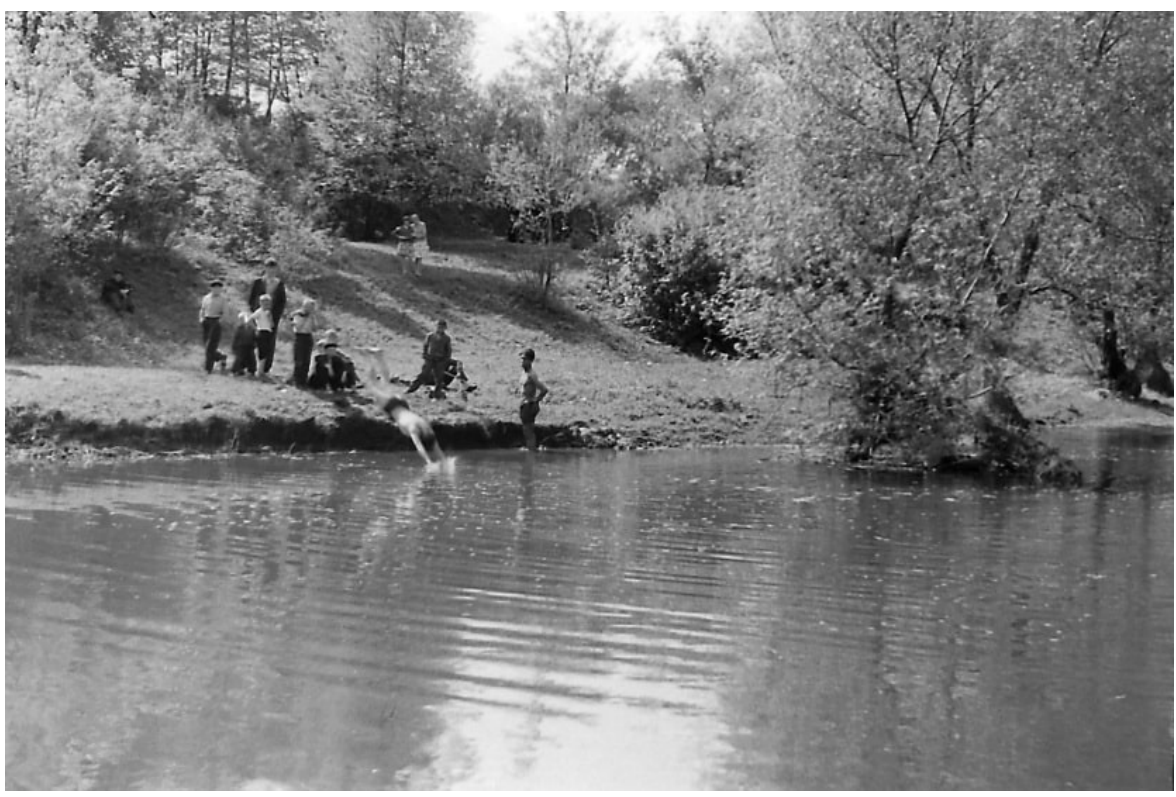

Рис. 5. Источник: интернет [23].

Обратимся теперь к истории формирования усадебного комплекса в части, касающейся появления парка. В книге Л. В. Кригер [4] сообщается, что одним из первых владельцев села является ка- питан Петрово-Соловово (1734-1799), вторымтитулярный советник Н. В. Дихтярёв, владевший усадьбой до 1829 года. В июне 1829 года имение было продано купцу Сергею Васильевичу Башкир- 


\section{Природользование}

цеву а от него перешло к сыну, Ивану Сергеевичу Башкирцеву, супругу М. В. Кольцовой- старшей сестры Воронежского поэта А. В. Кольцова, и одного из немногих его друзей. Место это приобрело большую известность среди состоятельных воронежцев, здесь бывали многие именитые столичные персоны, происходила масса интересных событий. Используя язык современных трендов [20], можно сказать, что И. С. Башкирцев занялся развитием местного событийного, эко- и т. д. туризма. В этот период усадьба и приобрела широкую известность и теперешний топоним. Необходимо отметить, что информация о том, на каких посетителей и на какие действа был рассчитан парковый комплекс, помогает восстановить его план. В частности, опыт функционирования садов во время правления Екатерины Великой, а в провинции и дольше, освещён в работе [31]. В 1848 г. была составлена опись имения, перешедшего в дальнейшем к Тимофеевым.

При этом Вера Ивановна Тимофеева - дочь С. И. Башкирцева. Так что преемственность была сохранена. Непосредственно к парку в описи относятся несколько строк. Сообщается, что близ дома находится сад в 6 десятин, в котором «плодовитых разного рода молодых деревьев до 3 тысяч корней и осажен молодыми липами, берёзами, сосной до 7 тысяч штук». О планировке, к сожалению, не сказано ничего. Можно предположить, что каждый из владельцев вносил свою лепту в формирование этого поместья. Тогда в посадках должно читаться несколько хронологических слоёв: деревья возрастом более 220 лет (первые владельцы); 220-170 лет (Башкирцевы); 170-100 лет (Тимофеевы); менее 100 лет - советский период. Распределение деревьев по возрастным группам интересно и с исторической точки зрения и с точки зрения устойчивости насаждений и степени их соответствия данному биотопу. После национализации для усадебного комплекса наступает период чрезвычайно турбулентной истории, материальных последствий которого мы ещё коснёмся. В войну усадьба была почти разрушена. В послевоенные годы над ней взял шефство Семилукский завод огнеупорного кирпича и, надо отдать ему должное, в 1956 году состоялось открытие восстановленного в меру то- гдашних скромных возможностей и понимания, усадебного комплекса, ставшего заводским профилакторием. После крушения Советского Союза объект оказался бесхозным, и по настоящий момент тихо разрушается. Забегая вперёд, автор всё же искренне надеется что усадьбу ожидает новое рождение. Однако вернёмся к планировке комплекса.

В дальнейшем будем следовать условным обозначениям документа, устанавливающего границы объекта [18] на план-схеме ООПТ (рис. 3). Площади садов в боскетах, если считать по существующим посадкам, приблизительно имеют следующие значения: Б1=2,3 га; Б2=1,7 га, Б3=2 га, Б4=1,6 га. Суммарная площадь, занятая на данный момент садом, равна 7,6 га.

На территорию, прилегающую к особняку, приходится порядка 0,3 га. Сохранившаяся площадь аллейных посадок, включая «Южный ландшафтный парк», на данный момент- порядка 2,9 га. Ширина аллей по центру стволов 4,5-5 м. На данный момент в боскетах сохранилось порядка 1250 плодовых деревьев, в основном яблонь. Деревья высажены по квадратам, посадочный интервал колеблется вокруг 7 м (рис. 4).

Средняя сомкнутость полога порядка 0,4 . Травянистый покров из местных устойчивых видов многолетников имеет площадь проективного покрытия порядка 0,9 . Большинство деревьев имеет 50-60-летний возраст, то есть высаживалось в процессе послевоенного восстановления, однако есть поистине уникальные экземпляры. На фотографии (рис. 6) представлена груша диаметром 84 см - по всей видимости, из посадок, перечисленных в описи 1848 года. Складной метр с шагом в 20 см держат студенты ВГТУ и ВГЛТА Михаил Копытин и Влад Володин.

Вернёмся теперь к описи. Указанная в ней площадь плодового сада- 6 десятин, то есть $\sim 6,5$ га. Посчитаем посадочные интервалы при квадратичном способе размещения исходя из указанного количества 3000 шт.:

$$
\Delta=\sqrt{6500 \mathrm{M}^{2} / 3000 ш \mathrm{~T}}=4,65 \mathrm{M} / \mathrm{um} .
$$




\section{Природопользование}

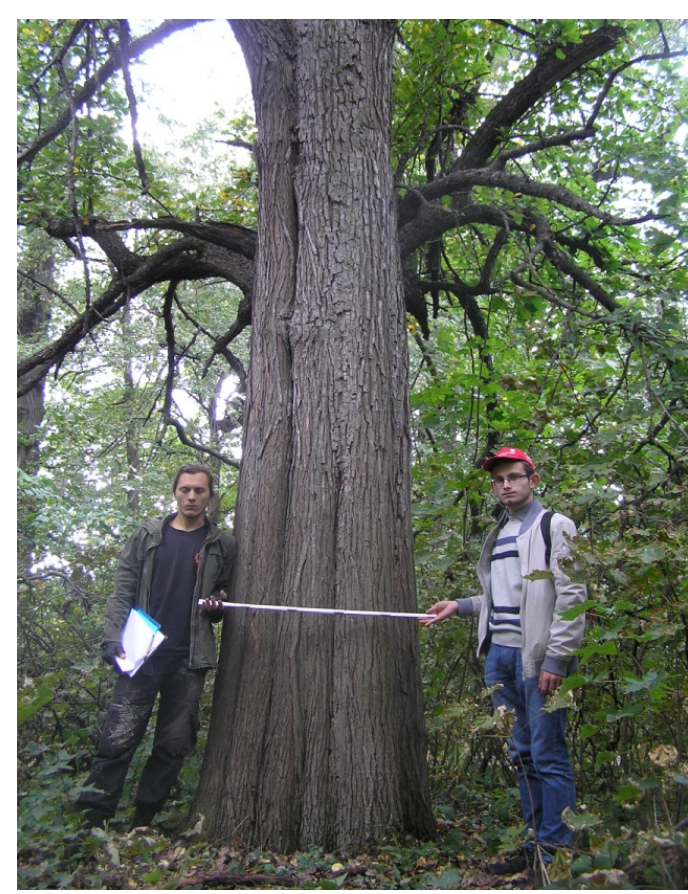

Рис. 6. Собственное фото авторов.

Вполне правдоподобная, фактически стандартная величина. По всей видимости, площадь сада возросла за счёт того, что на место утерянных фрагментов аллеи А4 и А3 после войны были высажены яблони. Попробуем теперь приблизиться к пониманию структуры аллей. Если посчитать площадь четырех боскетов по читаемым центральным линиям аллей, то мы получим величину $S_{5}=$ $240 \mathrm{~m} * 494 \mathrm{м}=118560 \mathrm{~m}^{2} \approx 11,8$ га.

Тогда площадь перекрестья из центральных аллей и опоясывающей «полуаллеи» будет: $S_{A}=$ $11,8-6,5=5,32 a$, что существенно больше регистрируемого сейчас. Зная суммарный периметр этой конструкции и площадь, ею занимаемую, получаем ширину лесозащитной полосы: 36 м.
Забегая вперёд скажем, что на наиболее сохранившихся участках А3 посадочный план вполне читаем. Лесозащитная полоса включала в себя 6 рядов с расстоянием между рядами 4,5-5 м, посадочным интервалом по ряду те же 4,5-5 м. Плюс разделительный промежуток перед плодовым садом 6,5 м (рис. 7). Липовая аллея - её центральная часть. Более чем основательная конструкция для создания благоприятного микроклимата и защиты от ветров и зноя.

Обратимся теперь к исследованию фактически уцелевших аллейных посадок. В ходе натурного обследования территории сначала выполнялся пересчёт и диагностика деревьев с занесением результатов в пересчётную ведомость, потом отбирались наиболее репрезентативные объекты и выполнялось бурение возрастным буравом. Предварительная оценка возраста насаждений осуществлялась на основе утверждённых таблиц и моделей хода роста [19]. На основании анализа кернов данные по ступеням толщины древостоев экстраполировались в возрастные ступени. При этом надо отметить, что имеющийся в распоряжении автора возрастной бурав позволяет отбирать керны максимум 28-сантиметровой глубины (рис. 8-10). Для точного определения возраста уникальных старовозрастных деревьев, произрастающих на территории ООПТ, необходимо использовать нетравматическое оборудование - например, резистограф. На фотографиях представлены керны деревьев с увеличением контрастности и подсчётом годовых колец. Образцы отобраны на участке А3 Б4 внешней стороны аллеи. Зелёным цветом выделено каждое десятое годичное кольцо.

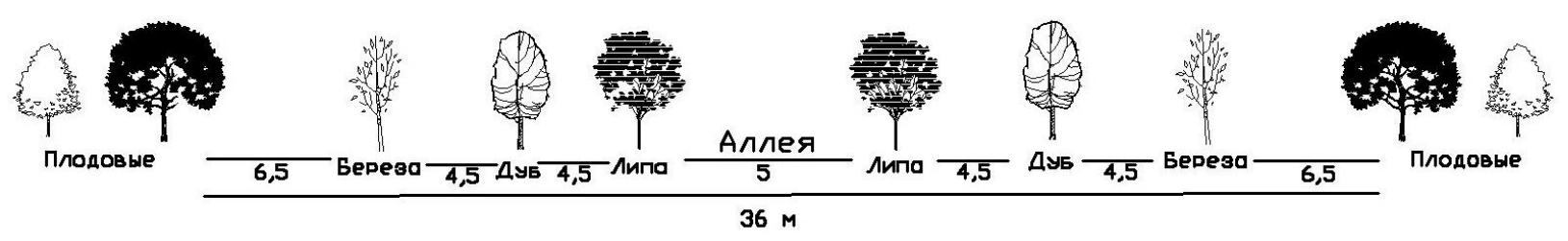

Рис. 7. А1, А2 в разрезе. Схема построена на основе собственных измерений авторов

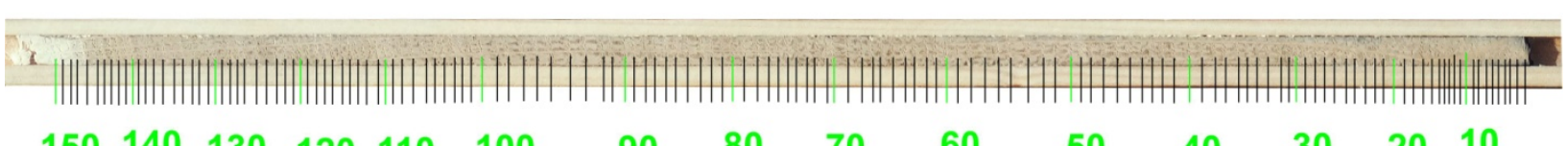

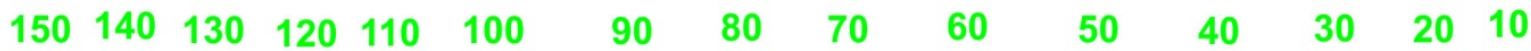

Рис. 8. Дуб. Керн 26,5 см. h=130 см. Всего на образце 150 годовых колец. Собственное фото авторов 


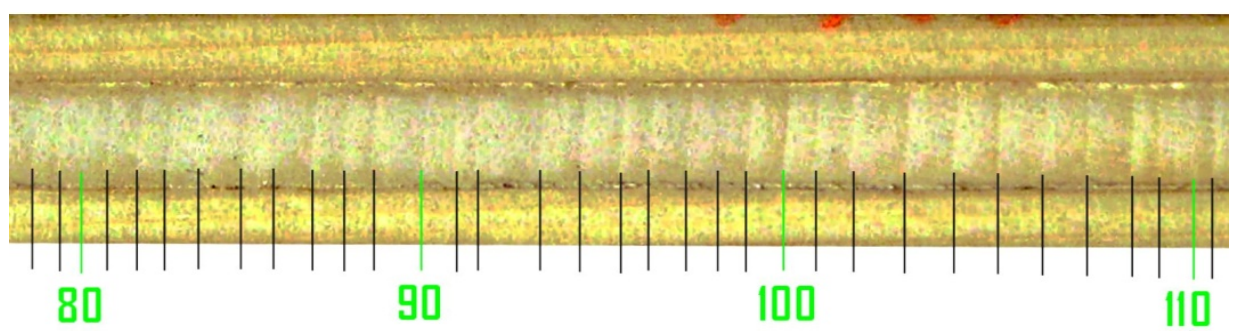

Рис. 9. Липа. Фрагмент керна 25,5 cм. h=80 см. Всего на образце 150 годовых колец. Собственное фото авторов
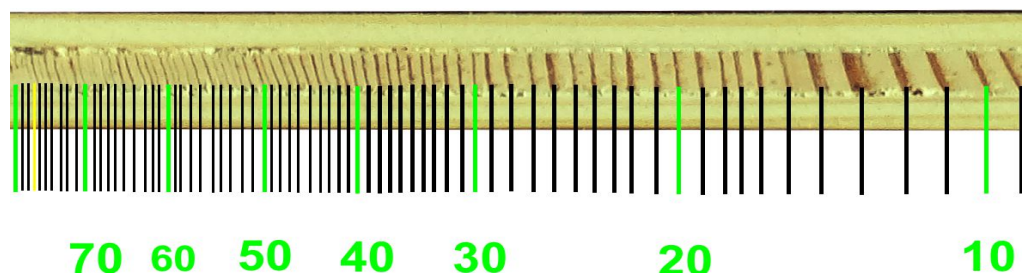

Рис. 10. Сосна. Фрагмент керна 17,5 см. h=1м. Всего на образце 139 годовых колец.

Собственное фото авторов

Также необходимо учесть коррекцию на возраст подроста, достигшего высоты взятия кернов. Возраст дубового подроста, достигшего высоты 130 см, составил 5 полных лет. Возраст липового подроста, достигшего 80 см, составил 3 года. Возраст ближайшего соснового подроста, достигшего высоты 1 м, составил 4 года. С учетом этой коррекции, возраст представленных деревьев определяется следующим образом: дуб - 155 лет; липа - 153 года; сосна - 144 года. Так как пересчётные ведомости имеют большой объём, для анализа степени сохранности аллейных посадок приведём сводную выборку из них по породному составу и ступеням толщины- возраста по участкам посадок в упрощённом варианте (табл. 1). Здесь указано количество деревьев с толщиной ствола $\mathrm{D} \geq 50$ см, так как их возраст при таких толщинах превышает 150 лет. Эта толщина очень характерна для насаждений данного объекта. С учё-

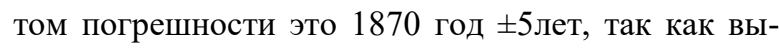
борка не очень велика. По всей видимости, это время частичной реконструкции посадок при Тимофеевых. А нас сейчас интересует вопрос генезиса территории ООПТ. Согласно результатам пересчета всего в аллейных посадках сохранилось 1043 дерева. Из них 820 лип, 68 дубов, 121 клён, 6 сосен и 28 деревьев других пород, образующих случайные включения. В основном это молодые груши, яблони, ясень, боярышник, клён ясенелистный. К старовозрастным относятся практически все сохранившиеся сосны, больше половины имеющихся дубов, но менее 10\% лип. Для понимания генезиса территории этих обобщенных данных недостаточно. Рассмотрим подробнее приведённую выше таблицу. Первое, что обращает на себя внимание это неоднородность. Если А1Б1 и А2Б2 почти идентичны в распределении по толщинам древостоя и породному составу, то АЗБ4 в этом от них кардинально отличается. Отметим сейчас следующее: дубы старше 150 лет статистически уверенно присутствуют на участках АЗБ4 - внешний и «южный парк». Это наиболее удалённые от особняка участки, находящиеся от него по диагонали к юго-востоку. И если есть старовозрастные дубы, то есть и такие же липы, присутствуют сосны. Кроме того, клён остролистный присутствует на АЗБ4 и на АЗБ2. И, наконец, очень мало деревьев на А4 и АЗБ2. Начнём с последнего. АЗБ2 почти полностью выпилен, что видно на спутниковом снимке (рис. 13). Остался 30-метровый участок перед перекрёстком с А2. От А4 уцелел также небольшой фрагмент, образующий перекрёсток с А2. Интереснее с А1. Эта аллея есть, угадываются посадочные интервалы $\pm 4,5$ м, и представлена почти исключительно липами с толщиной ствола $22 \sim 26 \mathrm{~cm}$ (рис. 11). 
Таблица 1

Породный состав по совокупности участков аллейных посадок. Источник: собственные вычисления авторов

\begin{tabular}{|c|c|c|c|c|c|c|c|c|c|c|c|c|c|c|}
\hline \multirow[t]{2}{*}{ Участок } & \multirow[b]{2}{*}{$\begin{array}{l}0 \\
\dot{0} \\
\text { D }\end{array}$} & \multicolumn{3}{|c|}{ Липа мелколистная } & \multicolumn{3}{|c|}{ Дуб черешчатый } & \multicolumn{3}{|c|}{$\begin{array}{l}\text { Клён } \\
\text { остролистный }\end{array}$} & \multicolumn{3}{|c|}{$\begin{array}{l}\text { Сосна } \\
\text { европейская }\end{array}$} & \multirow[b]{2}{*}{ 导 } \\
\hline & & 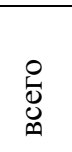 & $\begin{array}{l}\mathrm{D} \geq \\
50 \\
\text { ШT }\end{array}$ & $\begin{array}{l}\mathrm{D} \geq \\
50 \%\end{array}$ & 它 & $\begin{array}{l}\mathrm{D} \geq \\
50 \\
\text { ШТ }\end{array}$ & $\begin{array}{l}\mathrm{D} \geq \\
50 \\
\%\end{array}$ & 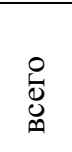 & $\begin{array}{l}\mathrm{D} \geq \\
50 \\
\text { ШT }\end{array}$ & $\begin{array}{l}\mathrm{D} \geq \\
50 \\
\%\end{array}$ & : & $\begin{array}{l}\mathrm{D} \geq \\
50 \text { шт }\end{array}$ & $\begin{array}{l}\mathrm{D} \geq \\
50 \%\end{array}$ & \\
\hline А1Б1 & 118 & 113 & 7 & 6,2 & 0 & 0 & 0 & 1 & 0 & 0 & 0 & 0 & 0 & 4 \\
\hline А1Б2 & 111 & 110 & 2 & 1,8 & 0 & 0 & 0 & 1 & 0 & 0 & 0 & 0 & 0 & 0 \\
\hline А1Б3 & 47 & 40 & 0 & 0 & 3 & 1 & 33,3 & 2 & 0 & 0 & 0 & 0 & 0 & 2 \\
\hline А1Б4 & 34 & 32 & 6 & 18,8 & 1 & 0 & 0 & 0 & 0 & 0 & 0 & 0 & 0 & 1 \\
\hline А2Б1 & 72 & 71 & 8 & 11,3 & 0 & 0 & 0 & 1 & 0 & 0 & 0 & 0 & 0 & 0 \\
\hline А2Б3 & 42 & 40 & 10 & 25 & 0 & 0 & 0 & 2 & 0 & 0 & 0 & 0 & 0 & 0 \\
\hline А2Б2 & 47 & 44 & 3 & 6,8 & 0 & 0 & 0 & 1 & 0 & 0 & 0 & 0 & 0 & 2 \\
\hline А2Б4 & 33 & 30 & 0 & 0 & 2 & 2 & 100 & 1 & 0 & 0 & 0 & 0 & 0 & 0 \\
\hline АЗБ2 & 12 & 9 & 0 & 0 & 0 & 0 & 0 & 2 & 0 & 0 & 0 & 0 & 0 & 1 \\
\hline $\begin{array}{l}\text { А3Б2 } \\
\text { Внеш- } \\
\text { ний }\end{array}$ & 139 & 76 & 0 & 0 & 22 & 6 & 27 & 29 & 0 & 0 & 0 & 0 & 0 & 12 \\
\hline А 354 & 145 & 91 & 0 & 0 & 9 & 3 & 33,3 & 41 & 2 & 4,9 & 1 & 1 & 100 & 3 \\
\hline $\begin{array}{l}\text { АЗБ4 } \\
\text { Внеш- } \\
\text { ний }\end{array}$ & 110 & 44 & 26 & 59 & 23 & 22 & 95,7 & 39 & 2 & 5,1 & 3 & 2 & 67 & 1 \\
\hline $\begin{array}{l}\text { «южный } \\
\text { парк» } \\
3.3\end{array}$ & 40 & 29 & 4 & 13,8 & 8 & 5 & 62,5 & 0 & 0 & 0 & 2 & 2 & 100 & 1 \\
\hline A4Б1 & 10 & 9 & 0 & 0 & 0 & 0 & 0 & 1 & 0 & 0 & 0 & 0 & 0 & 0 \\
\hline $\begin{array}{l}\text { А4Б1 } \\
\text { Внеш- } \\
\text { ний }\end{array}$ & 14 & 13 & 4 & 30,7 & 0 & 0 & 0 & 0 & 0 & 0 & 0 & 0 & 0 & 1 \\
\hline A4Б3 & 14 & 14 & 4 & 28,5 & 0 & 0 & 0 & 0 & 0 & 0 & 0 & 0 & & 0 \\
\hline $\begin{array}{l}\text { А4Б3 } \\
\text { Внеш- } \\
\text { ний }\end{array}$ & 55 & 55 & 18 & 32,7 & 0 & 0 & 0 & 0 & 0 & 0 & 0 & 0 & & 0 \\
\hline $\begin{array}{l}\text { Всего } \\
\text { по } \\
\text { участ- } \\
\text { кам }\end{array}$ & $\stackrel{\Re}{\Xi}$ & 820 & 92 & $7,6 \%$ & 68 & 39 & $57 \%$ & 121 & 4 & $3,3 \%$ & 6 & 5 & $83 \%$ & 28 \\
\hline
\end{tabular}




\section{Природользование}

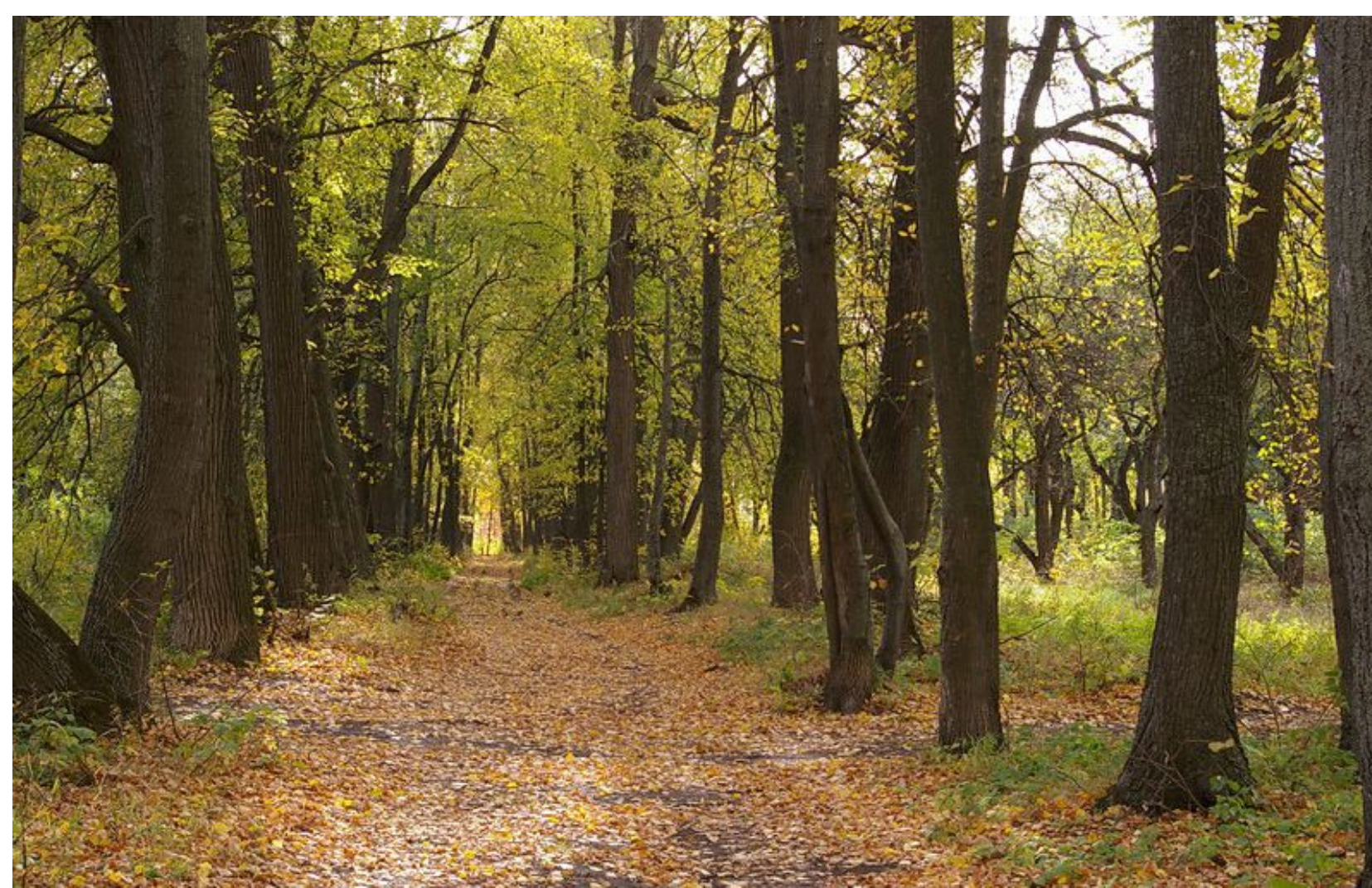

Рис. 11. Центральная аллея между боскетами Б1 и Б2. Направление юго-восток (к перекрёстку)

Собственное фото авторов.

Второго и третьего ряда нет, на расстоянии $15 \sim 17$ м от лип начинается яблоневый сад. Здесь необходимо пояснить, что о количестве рядов кроме гипотезы, следующей из баланса территории по описи 1848 года, можно судить по результатам обмеров наиболее сохранившегося участка АЗБ4 внешней стороны лесозащитной полосы. Там как раз присутствует второй дубовый ряд и на увалах, оставшихся от третьего ряда, растут две старовозрастные сосны. Именно они позволяют предположить, что указанные в описи сосны были использованы по внешнему периметру.

Но вернёмся к центральной аллее. Чтобы выяснить причины такого отличия между аллеями рассмотрим более подробно статистику по пересчетной ведомости участка А1Б1 (табл. 2). Как видно из таблицы, данная сторона аллеи состоит практически полностью из липы. Ясень и клён приречный - случайные гости. Больше трети лип имеют несколько стволов, и при ближайшем рассмотрении оказываются корневой порослью ранее спиленных деревьев. Не заросшие комлевые дупла присутствуют именно на них. Все они относятся к первой ступени толщины.

Исходя из откорректированной по кернам скорости роста, 22-28 см толщины соответствуют 70-77 лет жизни дерева, то есть 1943-1950 годы. Известно, что во время войны в особняке размещался госпиталь. Сразу после освобождения Воронежа от частей вермахта началось восстановление Семилукского огнеупорного завода, и в полуразрушенном здании усадьбы размещалось общежитие рабочих. Видимо, первым делом на строительные нужды и дрова пошли дубы из второго ряда А1. Косвенно это подтверждается тем, что дубы появляются лишь за перекрестком аллей, на А1Б3, А1Б4, А2Б4. Отсюда было дальше транспортировать.

В ходе послевоенного восстановления усадьбы выпавшие из первого ряда деревья были досажены. Такая же участь, очевидно, постигла и участок А4Б1, но только в 20-е годы. Ведь он расположен к особняку ближе, чем центральная аллея. На разведфото Люфтваффе 1942 года этот фраг- 


\section{Природопользование}

мент уже отсутствует (рис. 12). Уцелели некоторые старовозрастные деревья на участках склона, проблемных с точки зрения логистики если можно так сказать.

Таким образом, наименее пострадавшим от антропоморфного фактора по естественным причинам оказался участок АЗБ4 внешняя сторона, который мы рассмотрим далее. При этом необходимо отметить, что состояние имеющихся липовых посадок можно оценивать как хорошее, несмотря на отсутствие какого либо ухода и большую рекреационную нагрузку. К первым двум категориям состояния принадлежит 82 \% деревьев. Количество деревьев, поражённых болезнями или вредителями невелико, всего 3,5 \%. Основная про- блема после многоствольности и комлевых дупел нарушение геометрии ствола ввиду загущенности и механические повреждения от заезжающих сюда за яблоками «ГАЗелей» $(7,8$ \%). У большинства экземпляров не более 10 \% усыхания ветвей, в основном нижних. Несмотря на конец августа, здоровая листва не имеет даже начальной степени хлороза, столь характерного для областного центра.

Теперь перейдём к более детальному рассмотрению наиболее удаленного от особняка, и потому лучше всего сохранившегося, участка АЗБ4. Проанализируем статистическую выборку по данному участку, представленную в такой же форме, что и по А1Б (табл. 3).

Таблица 2

Сводная статистика по пересчётной ведомости А1Б1. Источник: собственные вычисления авторов.

\begin{tabular}{|c|c|c|c|c|c|c|c|c|c|c|c|c|c|c|c|c|}
\hline \multirow[b]{3}{*}{ Порода } & \multicolumn{16}{|c|}{ Участок центральной аллен вдоль боскета Б1 } \\
\hline & \multirow[b]{2}{*}{ 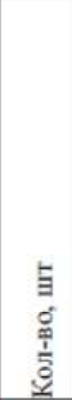 } & \multirow[b]{2}{*}{ 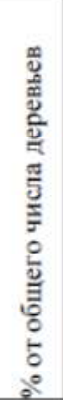 } & \multicolumn{4}{|c|}{$\begin{array}{l}\text { Ступени толшнны, в } \\
\%\end{array}$} & \multicolumn{5}{|c|}{$\%$ Категорин состояния } & \multicolumn{5}{|c|}{$\begin{array}{l}\text { Повреждения по типам, в \% от } \\
\text { общего чнсла деревьев }\end{array}$} \\
\hline & & & $\begin{array}{l}\Sigma \\
\text { z } \\
\text { ̀े } \\
\text { n் } \\
11\end{array}$ & 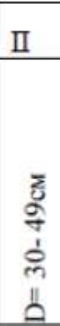 & 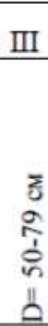 & $\begin{array}{l}\sum_{0}^{z} \\
\text { i } \\
\text { Al } \\
0\end{array}$ & 1 & 2 & 3 & & 5 & 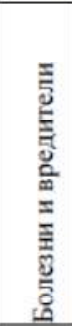 & 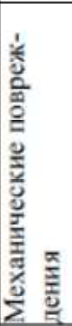 & 竞 & 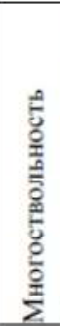 & 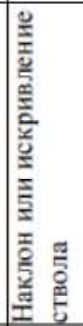 \\
\hline $\begin{array}{l}\text { Клён прн- } \\
\text { речный }\end{array}$ & 3 & 2.2 & 100 & 0 & 0 & 0 & 33 & 66 & 0 & 0 & 0 & 33 & 33 & 0 & 33 & 0 \\
\hline $\begin{array}{l}\text { лепа мелко- } \\
\text { листная }\end{array}$ & 114 & 97 & 81 & 18 & 1 & 0 & 17 & 65 & 17 & 0,5 & 0,5 & 3,5 & 7,8 & 3,5 & 34 & 19 \\
\hline ясень & 1 & 0,8 & - & 100 & 0 & 0 & 0 & 0 & 0 & 100 & 0 & 100 & 0 & 0 & 0 & 0 \\
\hline
\end{tabular}

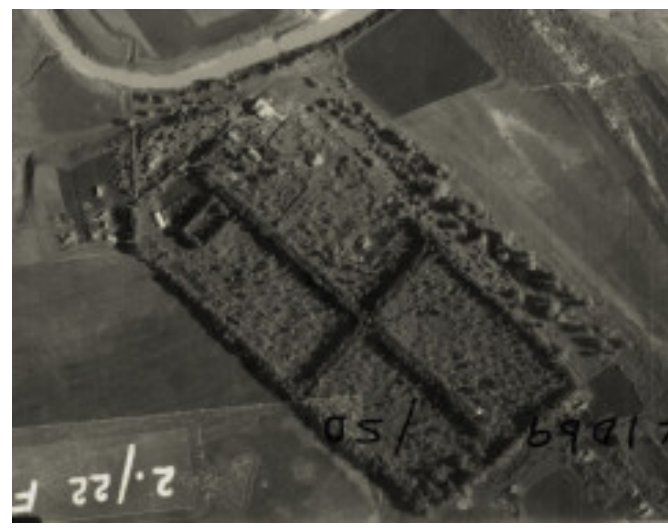

Рис. 12. Аэрофотосъёмка Люфтваффе, 1942 г.

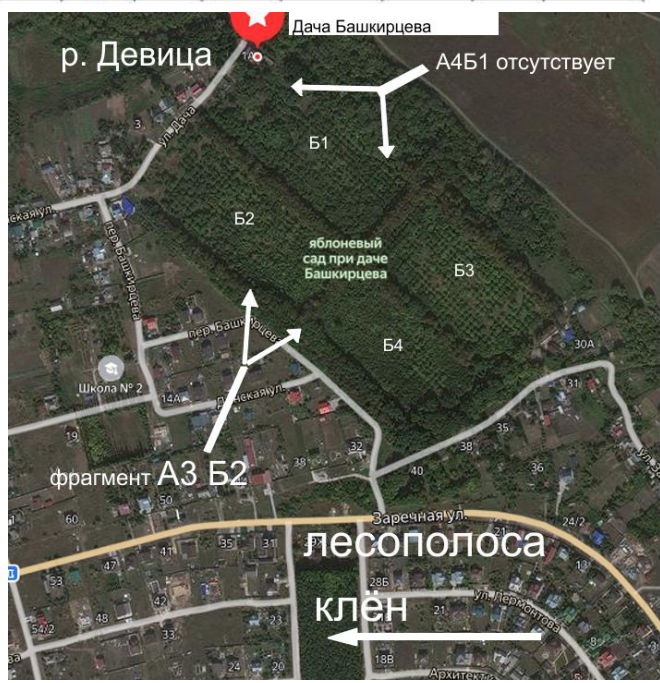

Рис. 13. Яндекс-карта с пометками авторов. Источник: интернет [23] 
Распределение по ступеням толщины фактически задаёт возрастной спектр древостоя. Обратим для начала внимание на то, что 90 \% клёна относится к I ступени толщины. Усреднённый диаметр по данному участку - 21,5 см. Возраст 60-70 лет, то есть послевоенные годы. Он - пришелец из соседствующей с ООПТ лесополосы, занявший практически освободившийся от сосен третий внешний ряд (рис. 13). Далее посмотрим на статистику дуба. Почти половина из имеющихся относится к IV ступени, а значит, старше 230 лет и были высажены до 1790 года. То есть- при первом упоминаемом владельце (капитан Петрово-Соловово), относящемуся к легендарному дворянскому роду. Липы такие то же есть, но их всего 7\%. Это говорит, во первых, о том, что по крайней мере АЗ была заложена тогда же целиком, а во вторых, о том, что в данном биотопе липа менее долговечна, нежели дуб. Хотя и чувствует себя хорошо - в основном 1 и 2 категория состояния. Следующая III ступень показывает этап реконструкции насаждений при
Башкирцевых, так как это возраст 190-200 лет и, соответственно, 1820-1830 годы. И это большая часть лип. Ступень II, соответственно, показывает реконструкцию насаждений, выполненную при Тимофеевых (рис. 14).

И, наконец, снова - I ступень толщины. Многоствольных деревьев как следствия вырубки здесь почти нет. Поэтому молодые деревьясеянцы. Однако из таблицы видно, что липа проигрывает в суксессионной битве более агрессивному клёну.

Остаётся выяснить почему от сосен, означенных в пересчётной ведомости 1848 года, осталось три дерева, одно из которых в критическом состоянии. Ведь при диаметре в 54 см возраст сосны в этом экотопе составляет 190 лет. Это 1830 год.

Обратимся к результатам изучения почвенного разреза, заложенного в верхней части парка (рис. 15). В первом приближении они представлены в таблице (табл. 4).

Таблица 3

Сводная статистическая таблица пересчётной ведомости АЗБ4 внешняя сторона

(Источник: собственные вычисления авторов)

\begin{tabular}{|c|c|c|c|c|c|c|c|c|c|c|c|c|c|c|c|c|}
\hline \multirow[b]{3}{*}{ Порода } & \multicolumn{16}{|c|}{ Участок аллен АЗ вдоль боскетаБ4 внешняя сторона } \\
\hline & \multirow[b]{2}{*}{$\begin{array}{l}\dot{1} \\
\dot{0} \\
\stackrel{0}{0} \\
\stackrel{0}{0}\end{array}$} & \multirow[b]{2}{*}{ 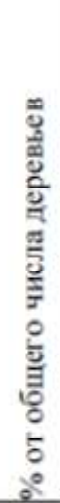 } & \multicolumn{4}{|c|}{$\begin{array}{l}\text { Ступени толшшины, } \\
\text { в } \%\end{array}$} & \multicolumn{5}{|c|}{$\%$ Категорни состояния } & \multicolumn{5}{|c|}{$\begin{array}{l}\text { Повреждения по типам, в \% } \\
\text { от обшего чнсла деревьев }\end{array}$} \\
\hline & & & 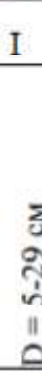 & I & $\begin{array}{l}z \\
0 \\
2 \\
\frac{1}{1} \\
0 \\
11 \\
0\end{array}$ & $\begin{array}{l}\sum_{0} \\
\text { o } \\
\text { Al } \\
0\end{array}$ & 1 & 2 & 3 & 4 & 5 & 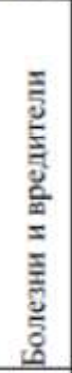 & 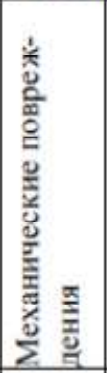 & $\frac{\mathrm{g}}{5}$ & 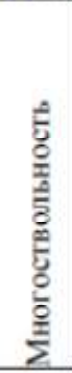 & 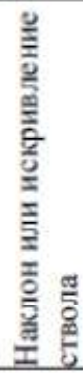 \\
\hline $\begin{array}{l}\text { дуб черешча- } \\
\text { тый }\end{array}$ & 23 & 21 & 4 & & 26 & 48 & 30 & 48 & 22 & - & - & - & - & - & 0 & 26 \\
\hline $\begin{array}{l}\text { ктён остроли- } \\
\text { стный }\end{array}$ & 39 & 36 & 90 & 8 & 2 & - & 36 & 54 & 10 & - & - & 3 & - & 3 & 0 & 15 \\
\hline $\begin{array}{l}\text { лита мелко- } \\
\text { лнстная }\end{array}$ & 44 & 40 & 41 & & 32 & 7 & 55 & 32 & 9 & 2 & 2 & 2 & 7 & & 2.7 & 11 \\
\hline $\begin{array}{l}\text { сосна евро- } \\
\text { пейская }\end{array}$ & 3 & 3 & - & & 67 & - & 33,3 & 33,3 & - & 33,3 & - & - & - & 33 & 0 & - \\
\hline
\end{tabular}




\section{Природопользование}

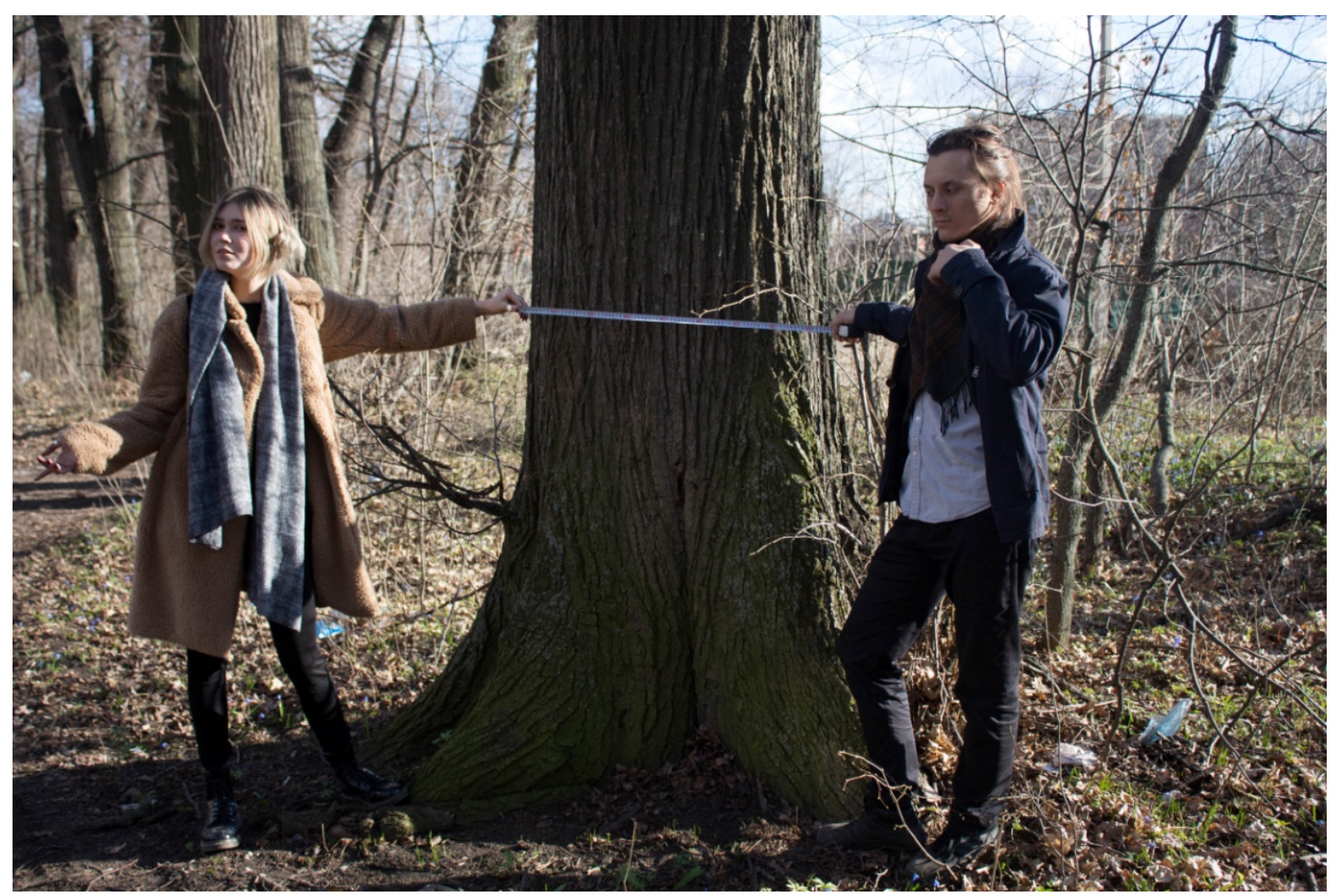

Рис. 14. Липы участка АЗБ4 внешняя сторона. Дерево IV ступени толщины. Собственное фото авторов. С рулеткой - студенты ВГТУ и ВГЛТА Арина Авилова и Влад Володин
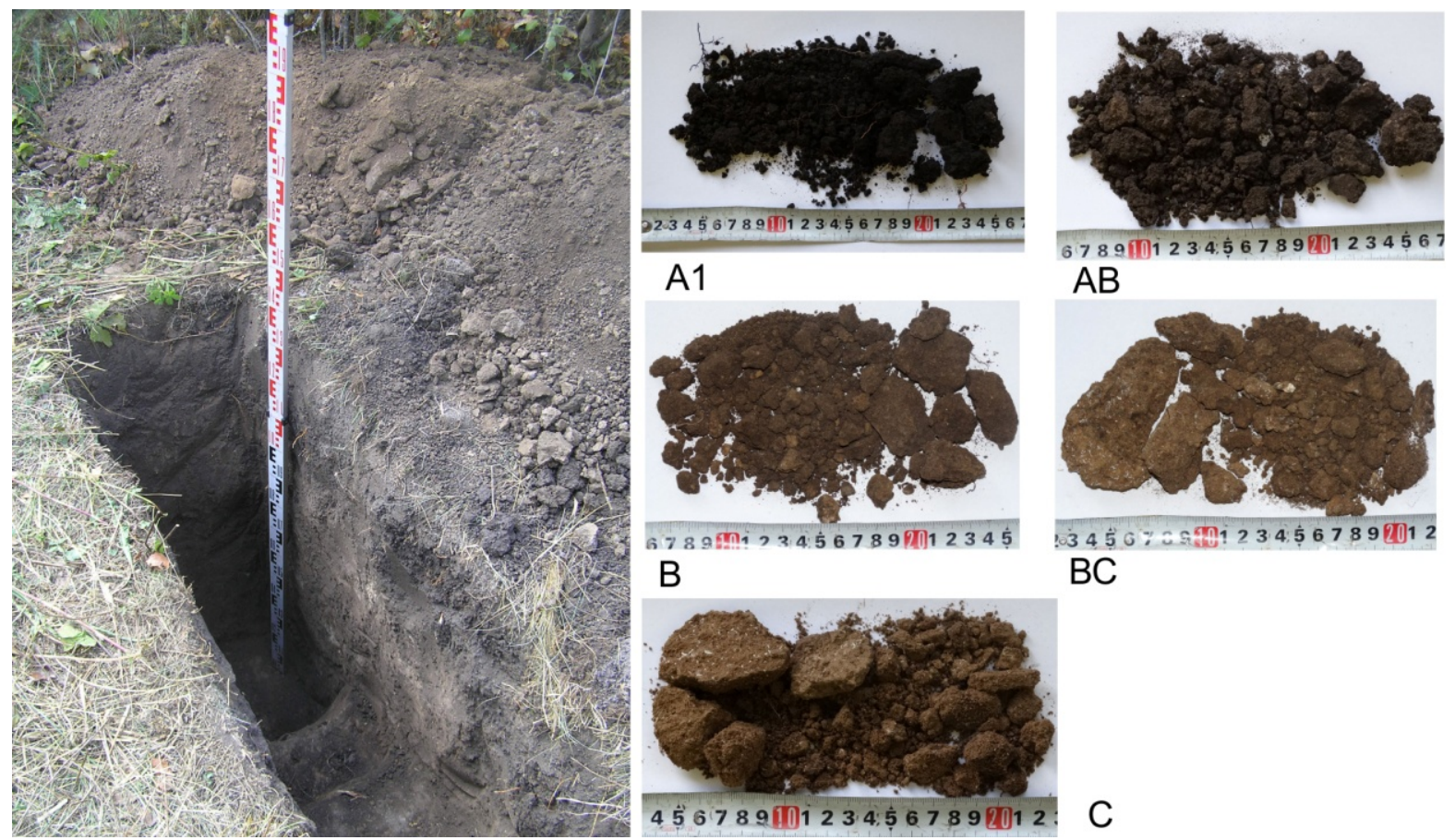

B

$3456 \%: 29891234567892012$

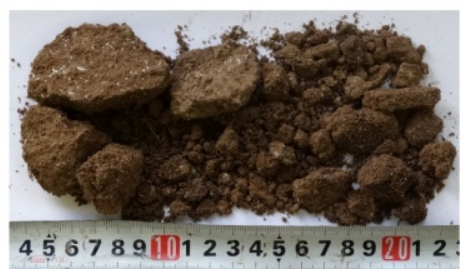

$\mathrm{BC}$

Рис. 15. Почвенный разрез боскет Б1. Собственное фото авторов 
Характеристики разреза. Собственные измерения авторов

\begin{tabular}{|c|c|c|}
\hline $\begin{array}{l}\text { Почвенный } \\
\text { слой }\end{array}$ & $\begin{array}{l}\text { Глубина } \\
\text { залегания, } \\
\text { см. }\end{array}$ & Описание \\
\hline A1 & $0-27$ & $\begin{array}{l}\text { Свежий, рыхлый, цвет тёмно-серый до чёрного, тяжёлый суглинок. Обиль- } \\
\text { ные корни, присутствуют включения мелкого гравия d=0.3 0.6 см. Комкова- } \\
\text { то- зернистая структура. }\end{array}$ \\
\hline $\mathrm{AB}$ & $27-55$ & $\begin{array}{l}\text { Свежий, рыхлый, цвет тёмно-серый с коричневым оттенком, тяжёлый суг- } \\
\text { линок. Присутствуют корни, известковые новообразования d 0,8 мм светло- } \\
\text { жёлтого цвета. Даёт вскипание HCL } 10 \% \text {. Структура комковато- зернисто- } \\
\text { пылевидная. }\end{array}$ \\
\hline B & $55-95$ & $\begin{array}{l}\text { Слой уплотнён. Тёмно-коричневый с охристым оттенком тяжёлый суглинок. } \\
\text { Присутствуют корни, известковые новообразования d 0,8 мм. Даёт вскипа- } \\
\text { ние HCL 10\%. Структура комковатая. }\end{array}$ \\
\hline $\mathrm{BC}$ & $95-130$ & $\begin{array}{l}\text { Охристо-коричневый с сероватым оттенком. Уплотнён, местами плотный. } \\
\text { Обильно присутствуют известковые новообразования. Даёт вскипание НСI } \\
\text { 10\%. Структура комковатая. }\end{array}$ \\
\hline $\mathrm{C}$ & $\begin{array}{l}130 \\
\text { глубже }\end{array}$ & $\begin{array}{l}\text { Коричневый, с охристым оттенком, уплотнённый слой. Глина. Обильное } \\
\text { присутствие новообразований в виде ложного мицелия. Единичные новооб- } \\
\text { разования в виде «журавчиков». Даёт вскипание НСI 10\%. Структура приз- } \\
\text { матически-пылевидная. }\end{array}$ \\
\hline
\end{tabular}

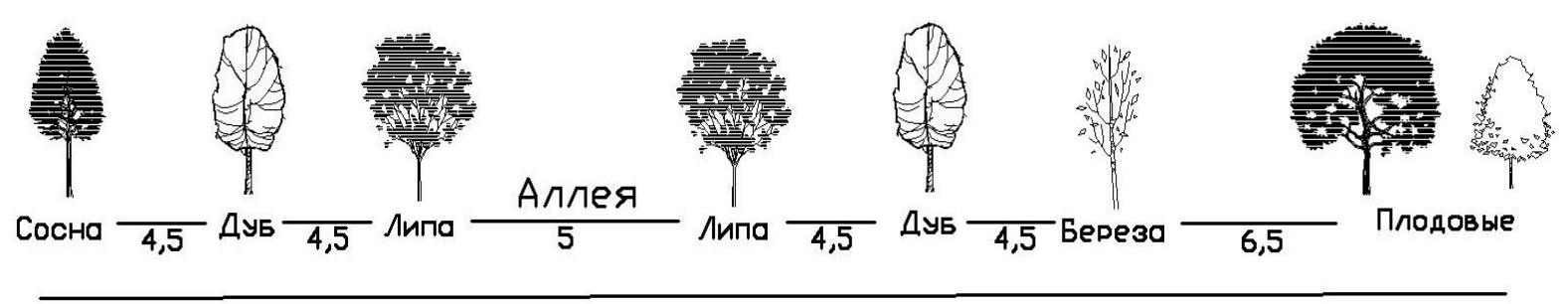

$36 M$

Рис. 16. А3, А4 в разрезе. Построено на основе собственных расчётов авторов

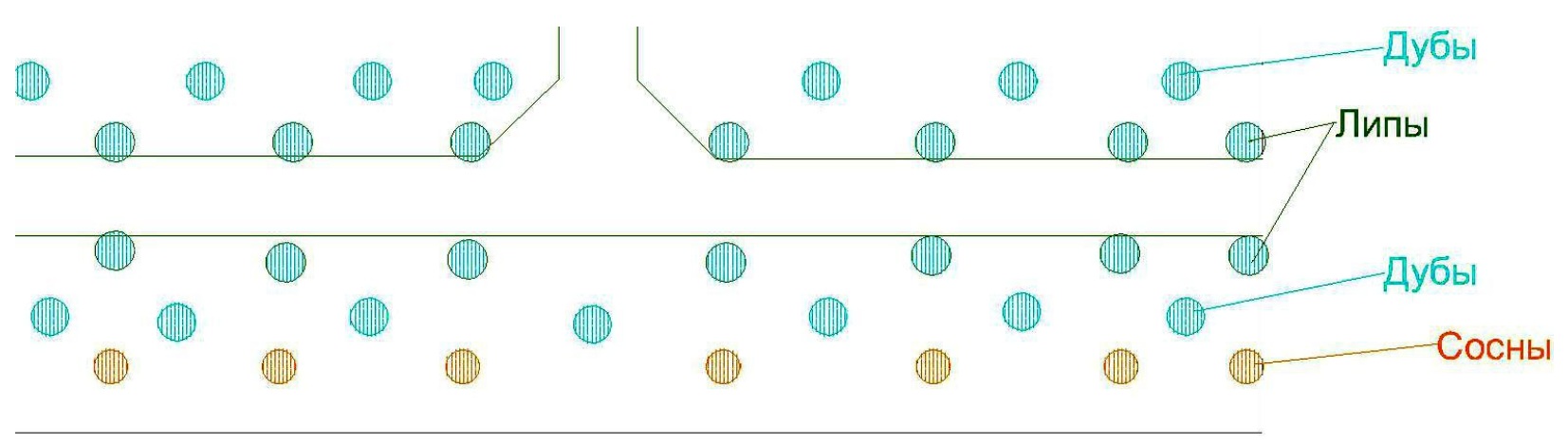

Рис. 17. Перекрёсток А2-А3.. Построено на основе собственных расчётов авторов 


\section{Природопользование}

Как видим, почва, начиная со слоя ВС имеет достаточно высокий уровень защелачивания вплоть до образования конкреций. Сосна обыкновенная может это переносить при посадке, но с трудом. Часто со временем развивается хлороз, теряется общая жизнестойкость. И, что главное, семена сосны обыкновенной в таких условиях не прорастают. У соснового ряда лесозащитной полосы не было шансов на возобновление в случае выпада или вырубки. Причиной отсутствия в сколько-нибудь заметном количестве сосен является неточный учёт экологических факторов. Однако теперь с полным основанием можно представить исходную структуру внешней лесозащитной полосы (рис. 16). Реконструкция плана посадок перекрёстка А2 и А3 показана на (рис. 17). Берёзовый ряд перед плодовыми не вошёл в кадр. Деревья расположены в шахматном порядке. Как уже говорилось выше, освободившаяся от выпавших сосен площадь третьего ряда зарастает кленовым, в основном, подлеском. На этом, казалось бы, можно и

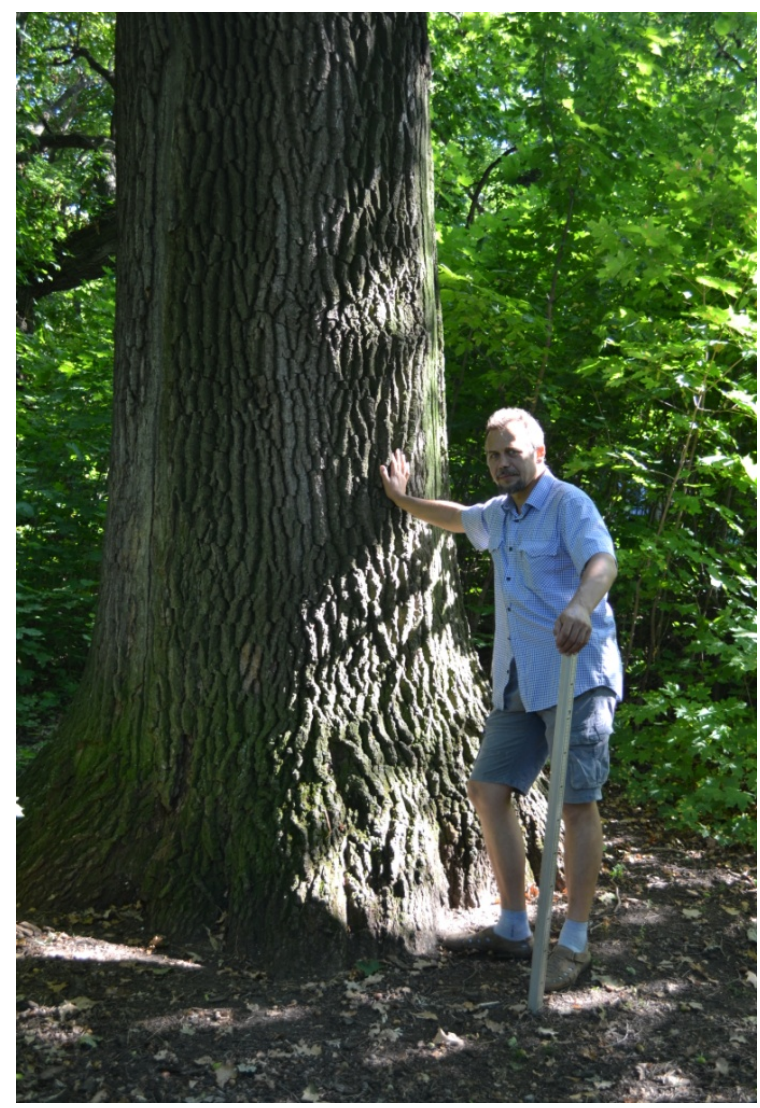

подытожить рассмотрение генезиса структуры посадок верхнего парка, но есть ещё одна интересная грань этого небольшого исследования, буквально стоящая во главе угла. Речь об уникальных старовозрастных деревьях, время жизни которых выходит за рамки известной истории этого места. Прежде всего это «Старший Брат» - так называют этого исполина местные старожилы (рис. 18, 19). С него начинается ряд дубовых посадок АЗБ4 по одну сторону и «южный парк» по другую.

Рядом чуть менее величественный «Младший Брат». Диаметр «Старшего Брата»- 137 см, что даёт показатель возраста 350-380 лет! Дерево буквально уходит корнями в 16-й век и является ровесником Петра Великого. И при этом - первая категория состояния! Высота - 25 метров. Автор присутствует на фотографии для масштаба.

Рядом находится сосна диаметром 78 см., что даёт оценочный возраст в 270 лет и 1750 год посадки, так как самостоятельно здесь прорасти она не могла. Есть и другие.

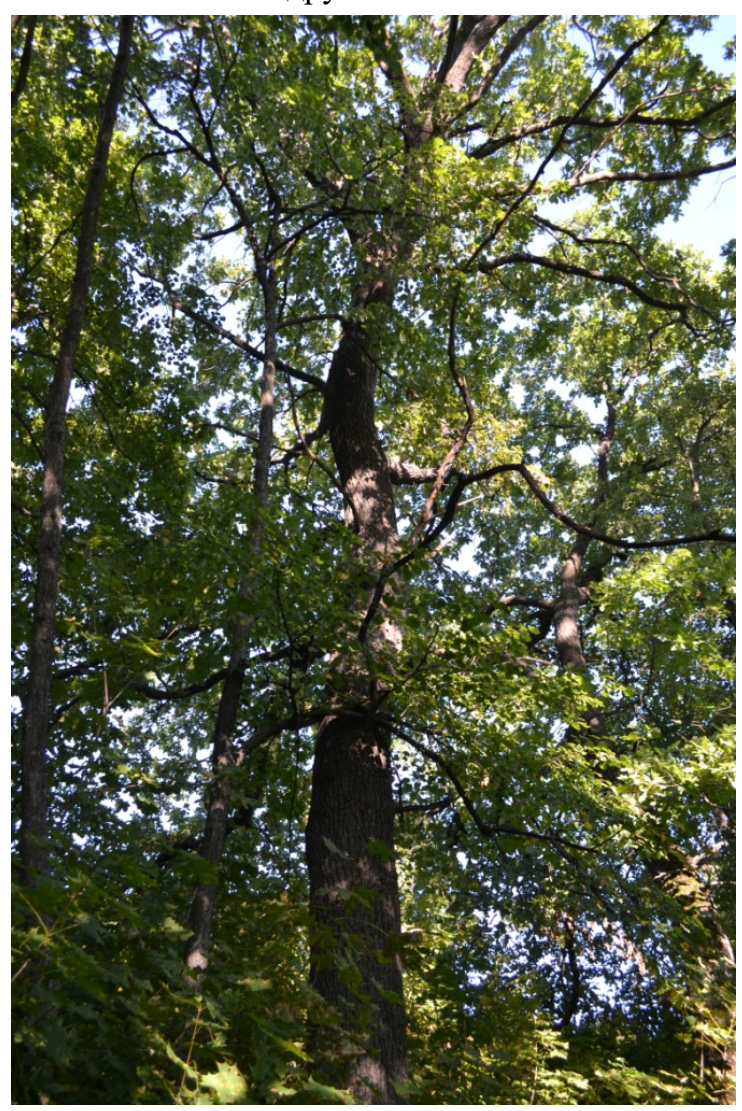

Рис. 18, 19. Дуб «Старший Брат», D =137 см. Собственное фото авторов 
Причём надо отметить, что уникальные деревья тяготеют к «южному парку». В частности, вышеозначенная сосна, хоть формально и попадает в участок АЗБ4. Их примерная локация показана на схеме планировочной структуры ООПТ заштрихованными кружками (рис. 20). Складывается впечатление, что планировочное решение отталкивается от этого реликтового участка. Неизвестный, увы, автор проекта включил в планировку сохранившийся участок насаждений, более древний, чем сама усадьба. Почему насаждений, а не естественной растительности? Южный угол, на котором возвышается «Старший Брат», существенно опущен относительно территории за пределами ООПТ при выравнивании площадки под будущий парк.
Изъятый отсюда грунт, очевидно, использован для отсыпки восточного угла боскета БЗ и, соответственно, восточного окончания аллеи А4. При желании и сейчас можно просчитать довольно значительный баланс перемещаемого грунта. «Старший Брат» вырос на уже подготовленной площадке. Естественными, по всей видимости, являются старовозрастные деревья, растущие на небольшом северном склоне «южного парка» ближе к центральной аллее. Вопрос же о том, кто занимался в начале петровских времён подготовкой площадки под будущий парк, для автора остаётся неразрешённым. Что лишь добавляет этому удивительному месту притягательности.

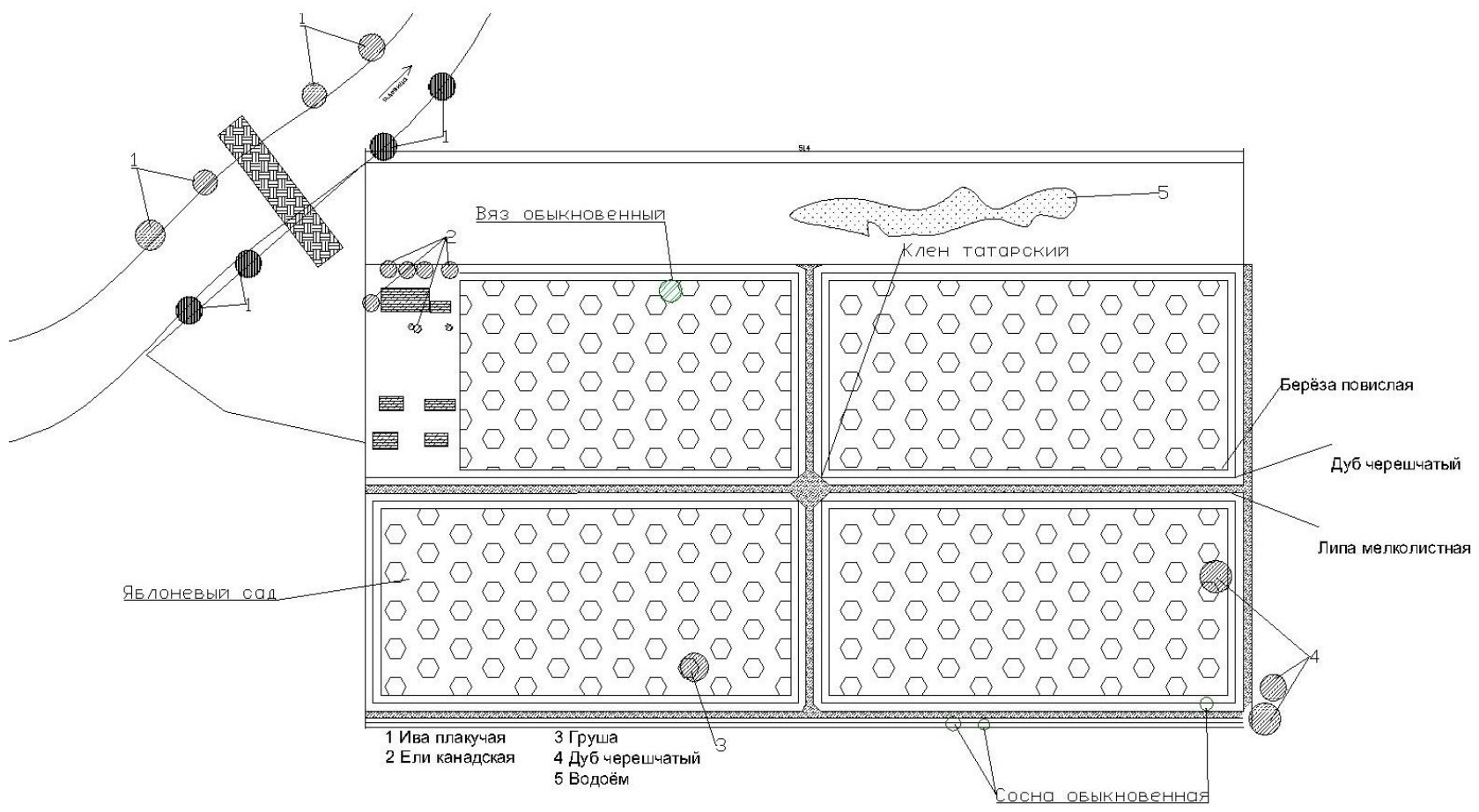

Рис. 20. План построен на основе собственных измерений авторов.

\section{Заключение}

Подведём теперь краткие итоги проведённого исследования. В ходе проведённой работы выявлена планировочная структура усадебного комплекса и её генезис. Особо подчеркну, что при переходе от владельца к владельцу эта архетипическая основа сохранялась, пережив даже варварство гражданской и отечественных войн. Выявлен породный и временной состав насаждений, их со- стояние. В посадках чётко читаются 5 этапов создания и реконструкций парка, выстраивая в единое историю его жизни. Особой ценностью обладают уникальные деревья и сохранившийся участок АЗБ4. По сути, они заслуживают статуса памятника природы внутри данной территории.

Несмотря на разрушительное антропоморфное воздействие, состояние уцелевших насаждений можно оценить как хорошее - у большинства де- 
ревьев 2 категория состояния. 52\% отклонений от нормы - нарушение геометрии ствола из-за отсутствия санитарных мероприятий и загущенности. Фактически это здоровые деревья. Ещё 10\% - механические повреждения. И только $5 \%$ - болезни и вредители (см. рис. 15). В середине лета, когда гораздо более молодые посадки в Воронеже уже теряют декоративность из-за хлороза и ожогов, здесь удивительно свежо и зелено.

Теургические условия по сравнению с окружающей застройкой чрезвычайно благоприятны. Благодаря открывающимся с коренного берега Дона видам, выходу к прозрачной прохладе реки Девица рекреационный потенциал этого места можно оценить как высокий.

Если учесть реалии сегодняшнего дня, то становится понятным, что для того, чтобы это уникальное место ожило, его необходимо включить в существующий сейчас поток бытия. И для этого есть все предпосылки. Особенно если учесть непростые времена, наступающие для международного туризма. Фактически надо продолжить линию развития местного эко-, культурно-, событийного и даже гастрономического туризма, начатую Башкирцевым. Благо есть опыт и зарубежных, и отечественных площадок, успешно развивающих это направление [20]. Соответственно, в случае разработки проекта реконструкции данной территории необходимо опираться на три реалии: культурноисторическую, ландшафтно-рекреационную и экологическую. В частности, при реконструкции третьего ряда лесозащитной полосы логично было бы использовать сосну крымскую или сосну горную, как устойчивые к щелочной реакции почвы, провести экспертизу актуальности использования берёзы бородавчатой по периметру плодовых садов и т. д.

Автор считает, что допустимо не только восстановить композицию парка по имеющимся данным, но и дополнить её элементами, раскрывающими вложенную в парк концепцию. Семиметровые расстояния между яблонями в боскетах а также их частичный выпад позволяет это сделать. Однако при этом необходимо провести полное ботаническое обследование территории с целью выявления уже сложившихся биоценозов, в част- ности среди травянистых многолетников в яблоневом саду. А также тщательно изучить возможность использования местных видов растений и видов, культивировавшихся в Воронежском регионе в 19 веке, чтобы не потерять при реконструкции неповторимость атмосферы.

Абсолютно необходимо раскрыть видовые окна на долину Дона с помощью санитарной обрезки, а местами и вырубки.

Однако самое главное - найти возможности реализации качеств этого замечательного места в сегодняшнем дне. Разработка организационной схемы реинтеграции подобных объектов в современную культурную и экономическую жизнь является серьёзной самостоятельной задачей. Подробно этот вопрос исследуется в частности в [32]. В западных странах с развитым туристическим сектором для этого существуют национальные и региональные программы, выстраивающие систему туристических кластеров.

У нас на данный момент превалирует точечный подход. Но тем не менее позитивные примеры регионального уровня тоже есть. Например в Воронежской области один из последних объектов, переживших второе рождение- парк имения Воронцовых, а теперь центральный Аннинский парк. Из прошедших реконструкцию наиболее близким по характеристикам к Даче Башкирцева является парк в посёлке Кокино Брянской области- бывшее имение дворянского рода Безобразовых. План поместья на первый взгляд совершенно иной (рис 21), но в структуре комплекса присутствуют те же архетипические элементы: трёхуровневое расположение на рельефе с верхним регулярным и нижним пейзажным парками; плодовые сады в боскетах, плотные липовые аллеи. Проект реконструкции был разработан ещё в 1950 году архитектором В. Городковым, но реализован лишь в настоящее время. Симптоматично, что памятник Ленину после реконструкции остался на месте. Теперь это тоже часть истории этого места (рис22). Таким образом, если оказывается возможным правильно определить место исторического парка в сегодняшнем дне, становится возможным решить и остальные задачи.

\section{Лесотехнический журнал 4/2020}




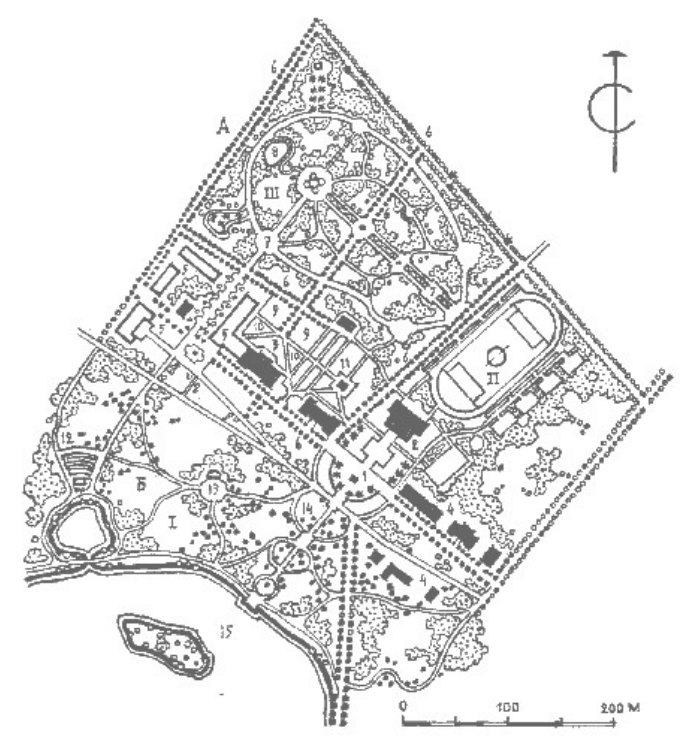

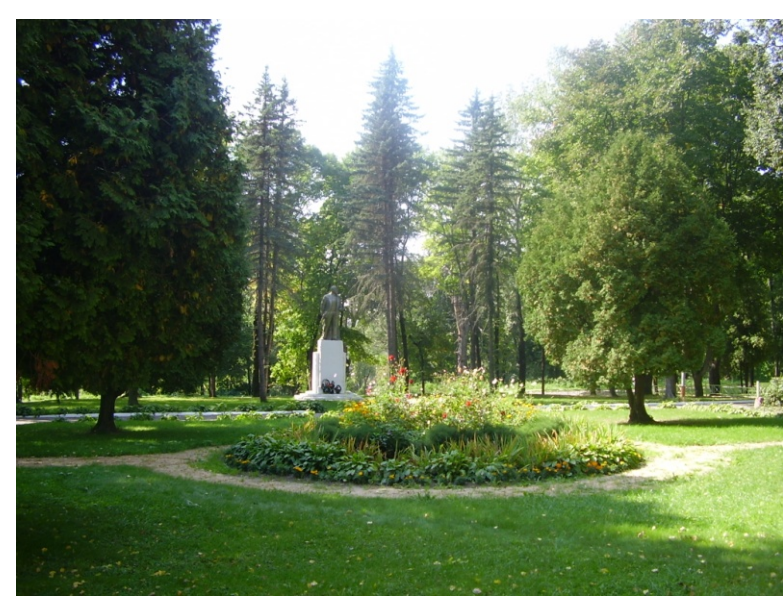

Рис. 22. Источник: интернет [23]

Рис. 21. Источник: интернет [23]

\section{Библиографический список}

1. Агальцова, В. Ф. Основы лесопаркового хозяйства: учебник для вузов / В. А. Агальцова// - Москва: ГОУ ВПО «МГУЛ», 2008. - 213 с.

2. Володин, В. В. Древесные насаждения ООПТ «Дача Башкирцева» как природный и культурноисторический памятник Воронежской земли / В. В. Володин // Журналистика и география: сборник материалов всероссийской научно-практической конференции. - Воронеж, 2020. - С. 169-175.

3. Ковтунов, В. И. Особенности лесоустройства лесов зеленых зон / В. И. Ковтунов // - Москва: Гослесбумиздат, 1962. - 45 с.

4. Кригер, Л. В. Усадьбы воронежской области / Л. В. Кригер // - Воронеж, 2011г. - 368с.

5. Кругляк, В. В. Самые знаменитые объекты ландшафтного, дендрологического и садово-паркового строительства центрально-чернозёмных областей России / В. В. Кругляк // Лесной вестник. Научноинформационный журнал. - 2010. - №1. - С. 31-36.

6. Лесная энциклопедия в 2 т. / под ред. Г. И. Воробьёва // - Т. 1 - Москва: советская энциклопедия, 1985. - 563 с. Т. 2 - Москва: Советская энциклопедия, 1986. - 621 с.

7. Ловелиус, Н. В. Изменчивость прироста деревьев, дендроиндикация природных процессов и антропогенных воздействий / Н. В. Ловелиус // Ленинград: издательство Наука, 1979. - 231 с.

8. Маевский, П. Ф. Флора средней полосы европейской части СССР / П. Ф. Маевский // 9-е испр. и доп. изд.; под ред. чл.-корр. АН СССР Б. К. Шишикина. - Ленинград: издательство Колос, 1964. - 880 с.

9. Матвеев, С. М., Румянцев, Д. Е. Дендрохронология / С. М. Матвеев, Д. Е. Румянцев // Воронеж: РИО ФГБОУ ВПО ВГЛТА, 2013. - 139 с.

10. Методические указания по обследованию памятников природы и государственных природных заказников: Утверждены приказом заместителя руководителя ФС ЛХ РФ Б. Филимонова 11.04.1995. - Москва, 1995. - 33 c. -http://docs.cntd.ru/document/9014277.

11. Отраслевой стандарт ОСТ 56-69-83. Площади пробные лесоустроительные: метод закладки / Введён 01.01.1984 // - Москва: издательство ЦБНТИ, 1984. - 59c.

12. Правила санитарной безопасности в лесах / утверждены постановлением правительства РФ от 29 июня 2007 г. № 414//. - Москва, 2007. - 6 с. 


\section{Природопользование}

13. Приказ Федерального агентства лесного хозяйства от 15 марта 2018 г. N 173 "О внесении изменений в Методические рекомендации по проведению государственной инвентаризации лесов", утвержденные приказом Рослесхоза от 10.11.2011 N 472". - URL: http://rosleshoz.gov.ru/doc/\%D0\%BF\%D1\%80_\%E2\%84\% 96173_2018.03.15.

14. Проскурина, Н. В. Роль дворянских усадеб в формировании системы расселения воронежской области / Н. В. Проскурина // Norwegian journal of development of the international science no 15/2018. c. 24-26.

15. Семенкова, И. Г. Фитопатология: учеб. для вузов / И. Г. Семенкова, Э. С. Соколова. - Москва: издательство Академия, 2003. - $480 \mathrm{c}$.

16. Степаницкий В. Б., Синицын М. Г. Методические рекомендации по организации особо охраняемых природных территорий регионального значения: справочное пособие / В. Б. Степаницкий, М. Г. Синицын // Красноярск: проект ПРООН/ГЭФ «Сохранение биоразнообразия в российской части Алтае-Саянского экорегиона».- 2008. - $140 \mathrm{c}$.

17. Тюльпанов, Н. М. Лесопарковое хозяйство / Н. М. Тюльпанов// - Л.: Стройиздат, 1975. - 159 с.

18. Управление по охране объектов культурного наследия воронежской области. Приказ от 10 мая 2016 года № 71-01-07/98 об утверждении границ территории объекта культурного наследия регионального значения "Дача Башкирцевых" (Воронежская область, г. Семилуки, улица Дача, 1а) / опубликован 16.03.2016.//https://pravo.govvrn.ru/content

19. Федеральное агентство лесного хозяйства. Международный институт прикладного системного анализа. Таблицы и модели хода роста и продуктивности насаждений основных лесообразующих пород северной Евразии / под ред. А. З. Швиденко // - Издание второе, дополненное. -Москва 2008. - 886 с.

20. Хайаш Пал. Деревни и маленькие города, как катализаторы развития сельских регионов / Пал Хайаш. - Москва: форум «Российское Село-2017». URL: http://mcx-consult.ru/d/pal_khayash_opyt_vengrii_ prezentatsiya2017.pptx.

21. Черепанов С. К. Сосудистые растения России и сопредельных государств / С. К. Черепанов// - СПБ, 1995. $-990 \mathrm{c}$.

22. Якименко О. В., Полунина И. В., Рудницких А. А. Усадьбы Семилукского муниципального района и их рекреационное значение / О.В. Якименко, И.В. Полунина, А.А. Рудницких // Лесотехнический журнал. 2017. - №1. - C. 104-1010.

23. Исторические фотографии усадьбы Башкирцева. - URL: https://pastvu.com/p/881514 (дата обращения 13.09.2020).

24. История и фотографии парка в посёлке Кокино Брянской области. - URL: https://bgsha.com (дата обращения 03.12.2020).

25. Jeffrey Young. Walking in London's parks and gardens/ Young Jeffrey // Publishers New Holland Publishers (UK). London, 1998, P. 223.

26. Iby, E. Schönbrunner Schlospark / E. Iby. - Leobersdorf: Stiepan Druck Ges. M.B.H., 2008. - 64 p.

27. Kurdiovsky R. The garden of Schönbrunn. Wien: Rezidenz Verlag, 2005. 144 c.

28. Newbury, Tim. The Ultimate Garden designer Word Losk, London/ Tim Newbury// 1995, p. 256.

29. Turner, T. Open space planning in London. / T. Turner // Strategic Planning Advice for London, october, 1988. - London, 1993. - P. 366-386.

30. Schönle A. Garden of the Empire: Catherine's Appropriation of the Crimea // Slavic Review. 2001. № 60/1. P. 1 -- 23.

31. Floryan M. Gardens of the Tzars: A Study of the Aesthetics, Semantics and Uses of Late 18th Century Russian Gardens. Aarhus, 1996.

32. Stephanie Mansourian, Gretchen Walters and Emily Gonzales. Identifying governance problems and solutions for forest landscape restoration in protected area landscapes // PARKS 25.1. May, 2019. 


\section{References}

1. Agal'tsova, V. F. Osnovy lesoparkovogo khozyaystva [ Fundamentals of forestry]. - Moscow: GOU VPO «MGUL» publ, 2008. - 213 p. (in Russian).

2. Volodin, V. V. Drevesnye nasazhdeniya OOPT «Dacha Bashkirtseva» kak prirodnyy i kul'turno-istoricheskiy pamyatnik Voronezhskoy zemli [Tree plantations of the SPNA "Bashkirtseva's Dacha" as a natural, cultural and historical monument of the Voronezh land]. Zhurnalistika i geografiya: sbornik materialov vserossiyskoy nauchnoprakticheskoy konferentsii [Journalism and geography: collection of materials of the All-Russian scientific and practical conference]. - Voronezh, 2020. - pp. 169-175 (in Russian).

3. Kovtunov, V. I. Osobennosti lesoustroystva lesov zelenykh zon [Features of forest management of green zones ]. - Moskva: Goslesbuizdat , 1962. - 45 p. (in Russian).

4. Kriger, L. V. Usad'by voronezhskoy oblasti [Manors of the Voronezh region]. Voronezh, 2011. -368 p. (in Russian).

5. Kruglyak, V. V. Samye znamenitye ob"ekty landshaftnogo, dendrologicheskogo i sadovo-parkovogo stroitel'stva tsentral'no-chernozemnykh oblastey Rossii [The most famous objects of landscape, dendrological and landscape gardening of the central black earth regions of Russia]. Lesnoy vestnik. Nauchno- informatsionnyy zhurnal [Forest Bulletin. Scientific information journal]. -2010. -№1. - pp. 31-36 (in Russian).

6. Lesnaya entsiklopediya $\vee 2 \mathrm{t}$ pod red. G. I Vorob'eva [Forest encyclopedia in 2 volumes edited by G. I. Vorobyov ]. Volume 1 - Moscow: Sovetskaya entsiklopediya [Soviet encyclopedia], 1985. - 563 p. Volume 2 Moscow: Sovetskaya entsiklopediya [Soviet encyclopedia], 1986, 621 p. (in Russian).

7. Lovelius, N. V. Izmenchivost' prirosta derev'ev, dendroindikatsiya prirodnykh protsessov i antropogennykh vozdeystviy [Variability of tree growth, dendroindication of natural processes and anthropogenic influences]. Leningrad: Nauka publ., 1979, 231 p. (in Russian).

8. Maevskiy, P. F. Flora sredney polosy evropeyskoy chasti SSSR [Flora of the middle zone of the European part of the USSR / PF Maevsky]. 9-e ispr. i dop. izd.; pod red. chl.-korr. AN SSSR B. K. Shishikina [9th revised and supplemented edition edited by Corresponding Member of the USSR Academy of Sciences BK Shishikin ]. Leningrad: Kolos publ., 1964, 880 p. (in Russian).

9. Matveev, S. M., Rumyantsev, D. E. Dendrokhronologiya [Dendrochronology]. Voronezh: RIO FGBOU VPO VGLTA publ, 2013, 139 p. (in Russian).

10. Metodicheskie ukazaniya po obsledovaniyu pamyatnikov prirody i gosudarstvennykh prirodnykh zakaznikov [Guidelines for the survey of natural monuments and state natural reserves]: Utverzhdeny prikazom zamestitelya rukovoditelya FS LKh RF B.Filimonova [Approved by the order of the Deputy Head of the Federal Forestry Service of the RF LH B. Filimonov] 11.04.1995. Moscow, 1995, 33 p. (in Russian). http://docs.cntd.ru/document/9014277.

11. Otraslevoy standart OST 56-69-83[Industry standard OST 56-69-83]. Ploshchadi probnye lesoustroitel'nye: metod zakladki [Trial forest management areas: the method of bookmarking]. -Moscow: TsBNTI publ, 1984, 59 p. (in Russian).

12. Pravila sanitarnoy bezopasnosti v lesakh [Rules of sanitary safety in forests]. Utverzhdeny postanovleniem pravitel'stva RF ot 29 iyunya 2007 g. № 414 [approved by the decree of the government of the Russian Federation of June 29, 2007 №. 414]. Moscow, 2007, 6 p. (in Russian).

13. Prikaz Federal'nogo agentstva lesnogo khozyaystva ot 15 marta 2018 g. N 173 "O vnesenii izmeneniy v Metodicheskie rekomendatsii po provedeniyu gosudarstvennoy inventarizatsii lesov ", utverzhdennye prikazom Rosleskhoza ot 10.11.2011 N 472" [Order of the Federal Forestry Agency dated March 15, 2018 N 173 "On Amendments to the Methodological Recommendations for Conducting State Forest Inventory", approved by order of the Federal Forestry Agency dated November 10, 2011 № 472 "] (in Russian). http://rosleshoz.gov.ru/doc/\%D0\%BF\%D1\%80_\%E2\%84\%96173_2018.03.15. 
14. Proskurina, N. V. Rol' dvoryanskikh usadeb v formirovanii sistemy rasseleniya voronezhskoy oblasti [The role of noble estates in the formation of the settlement system of the Voronezh region]. -Norwegian journal of development of the international science № 15/2018, pp. 24-26 (in Russian).

15. Semenkova, I. G., Sokolova, E. S. Fitopatologiya [Phytopathology] Moscow: Akademiya publ., 2003, 480 p. (in Russian).

16. Ctepanitskiy V. B., Sinitsyn M. G. Metodicheskie rekomendatsii po organizatsii osobo okhranyaemykh prirodnykh territoriy regional'nogo znacheniya: spravochnoe posobie [Methodological recommendations for the organization of specially protected natural areas of regional significance: a reference manual]. Krasnoyarsk: proekt PROON/GEF «Sokhranenie bioraznoobraziya v rossiyskoy chasti Altae-Sayanskogo ekoregiona» [UNDP / GEF project "Conservation of biodiversity in the Russian part of the Altai-Sayan ecoregion. "]. 2008, 140 p. (in Russian).

17. Tyul'panov, N. M. Lesoparkovoe khozyaystvo [Forest and park economy]. - Leningrad: Stroyizdat publ., 1975, 159 p. (in Russian).

18. Upravlenie po okhrane ob"ektov kul'turnogo naslediya voronezhskoy oblasti [Department for the protection of objects of cultural heritage of the Voronezh region]. Prikaz ot 10 maya 2016 goda № 71-01-07/98 ob utverzhdenii granits territorii ob"ekta kul'turnogo naslediya regional'nogo znacheniya "dacha Bashkirtsevykh" (Voronezhskaya oblast', g. Semiluki, ulitsa Dacha, 1a)[ Order of May 10, 2016 No. 71-01-07 / 98 on the approval of the boundaries of the territory of the cultural heritage site of regional significance "Bashkirtsevs dacha" (Voronezh region, Semiluki, Dacha street, 1a) ]. Voronezh: 16.03.2016 (in Russian). - https://pravo.govvrn.ru/content.

19. Federal'noe agentstvo lesnogo khozyaystva. Mezhdunarodnyy institut prikladnogo sistemnogo analiza. pod red. Shvidenko A. Z. [Federal Agency for Forestry. International Institute for Applied Systems Analysis. Edited by Shvidenko A. Z.]. Tablitsy i modeli khoda rosta i produktivnosti nasazhdeniy osnovnykh lesoobrazuyushchikh porod severnoy Evrazii [Tables and models of the course of growth and productivity of plantations of the main forest-forming species of northern Eurasia]. Moscow 2008, 886 p. (in Russian).

20. Hayash Pal. Derevni i malen'kie goroda, kak katalizatory razvitiya sel'skikh regionov [Villages and Small Towns as Catalysts for Rural Development]. - Moscow: forum «Rossiyskoe Selo-2017» [Forum "Russian Village2017"] (in Russian). - http://mcx-consult.ru/d/pal_khayash_opyt_vengrii_prezentatsiya2017.pptx.

21. Cherepanov S. K. Sosudistye rasteniya Rossii i sopredel'nykh gosudarstv [Vascular plants of Russia and neighboring countries]. SPB publ., 1995, 990 p. (in Russian).

22. Yakimenko O. V., Polunina I. V., Rudnitskikh A. A. Usad'by Semilukskogo munitsypal'nogo rayona i ikh rekreatsionnoe znachenie [The estates of the Semiluksky municipal district and their recreational value]. Lesotekhnicheskiy zhurnal [Forestry Engineering Journal], 2017, №1, pp. 104-1010 (in Russian).

23. Historical photographs of the Bashkirtsev estate. - URL: https://pastvu.com/p/881514 (accessed 13.09.2020)

24. History and photos of the park in the village of Kokino, Bryansk region. - URL: https://bgsha.com (accessed 03.12.2020).

25. Jeffrey Young. Walking in London's parks and gardens. Publishers New Holland Publishers (UK). London, 1998 , p. 223.

26. Iby E. Schönbrunn Palace Park. Leobersdorf: Stiepan Druck Ges. M.B.H., 2008, 64 p.

27. Kurdiovsky R. The garden of Schönbrunn. Wien: Rezidenz Verlag, 2005. 144 c.

28. Newbury, Tim. The Ultimate Garden designer Word Losk, London, 1995, p. 256.

29. Turner, T. Open space planning in London. Strategic Planning Advice for London, October, 1988, London, 1993, pp. 366-386.

30. Schönle A. Garden of the Empire: Catherine‘s Appropriation of the Crimea // Slavic Review. 2001. № 60/1. P. 1-23. 


\section{Природользование}

31. Floryan M. Gardens of the Tzars: A Study of the Aesthetics, Semantics and Uses of Late 18th Century Russian Gardens. Aarhus, 1996.

32. Stephanie Mansourian, Gretchen Walters and Emily Gonzales. Identifying governance problems and solutions for forest landscape restoration in protected area landscapes // PARKS 25.1. May, 2019.

\section{Сведения об авторах}

Володин Виктор Владимирович - аспирант ФГБОУ ВО «Воронежский государственный лесотехнический университет имени Г.Ф. Морозова», главный инженер ландшафтной студии «7 ключей», г. Воронеж, Российская Федерация; e-mail: vpark.vrn@mail.ru.

Харченко Николай Николаевич - доктор биологических наук, профессор, заведующий кафедрой экологии, защиты леса и лесного охотоведения ФГБОУ ВО «Воронежский государственный лесотехнический университет имени Г.Ф. Морозова», г. Воронеж, Российская Федерация; e-mail: forest.vrn@gmail.com.

Трегубов Олег Викторович - кандидат сельскохозяйственных наук, заведующий отделом биологического разнообразия, рационального лесопользования и лесовыращивания ФГБУ «ВНИИЛГИСбиотех», г. Воронеж, Российская Федерация; e-mail: o.v.tregubov@gmail.com.

\section{Information about authors}

Volodin Viktor Vladimirovich - postgraduate student, FSBEI HE "Voronezh State University of Forestry and Technologies named after G.F. Morozov", chief engineer of the landscape Studio "Seven clues", Voronezh, Russian Federation; e-mail: vpark.vrn@mail.ru.

Kharchenko Nikolay Nikolaevich - DSc (Biology), Professor, head of the Department of ecology, forest protection and forest hunting, FSBEI HE "Voronezh State University of Forestry and Technologies named after G.F. Morozov", Voronezh, Russian Federation; e-mail: forest.vrn@gmail.com.

Tregubov Oleg Viktorovich - PhD (Agriculture), head of the Department of biological diversity, rational forest management and reforestation, Voronezh, Russian Federation; e-mail: o.v.tregubov@gmail.com. 